\title{
Zobrazenie nel'ahkého osudu Slovákov na Žitnom ostrove v trilógii Ivana Habaja Kolonisti
}

\author{
Patrik Šenkár
}

\section{The image of the not easy fate of the Slovaks on the Rye Island in the trilogy of Ivan Habaj Kolonisti (Colonists)}

\section{Abstract}

The paper points to the literary image of the everyday life of Slovaks in southern Slovakia. However, this Rye Island existence is panhuman - even determinative - behind historical events of the turbulent 20th century. In the monumental (up to nine hundred pages) and in an artistically strong way, the trilogy (and hence the paper) describes the complicated (and not always idyllic) coexistence of Slovaks and Hungarians in this space-time: their problems, conflicts, desires and expectations. The metatext also gradually introduces the broader scope of Ivan Habaj's biobibliography and him as an important author of the Slovak South in the cross-section of the specifics of his continuous literary work. Emphasis is placed on his emblematic trilogy Kolonisti (Colonists), which provides a cross-section of the time, surroundings and characters of chronotope. It is also mentioned by various literary-critical responses to origins, using both analysis and synthesis. Thanks to the gradually applied interpretative objective-subjective approach to prototexts, the perceptive reader can learn about the troubled fate of Slovak colonists who during the difficult historical periods of 1918 , $1938,1945,1965 \ldots$.. lived (and metaphorically still live) their not easy life in this corner of our homeland.

Keywords: Slovaks; Rye Island; historical events; colonization; coexistence; interpretation

Kl'účové slová: Slováci; Žitný ostrov; historické udalosti; kolonizácia; spolužitie; interpretácia

Subject-Affiliation in New CEEOL: Language and Literature - Studies of Literature

- Slovakian Literature

DOI: $10.36007 /$ eruedu.2020.4.066-093

Venované jubilejnému 40. výročiu vydania Kolonistov; pamiatke 55. výročia ničivej povodne (aj) v našom okrese

a 75. výročia návratu kolonistov na južné Slovensko

Spisovatel' musí verit' predovšetkým svojmu vnútornému hlasu. Musí íst' svojou cestou; ak treba i zanovito a mat' pritom svoju stratégiu. Pre neho je dôležitá úprimnost' a naliehavost' umeleckej výpovede, pričom vo svojej tvorbe „hl'adá pravdivú odpoved' na otázky o zmysle l'udského života, o úlohe a význame lásky, nenávisti, vernosti, dočasnosti i večnosti“ (Bugárová 1985, 3). 
Takýmto autorom je dozaista aj slovenský spisovatel' Ivan Habaj, ktorý sa narodil 15. mája 1943 v Urminciach (okres Topol'čany). V rokoch 1957 - 1960 sa učil v spojárskej škole v Bratislave. Po jej ukončení pracoval ako mechanik a technik Okresnej správy spojov v Topol'čanoch (1960 - 1965). Strednú školu pre pracujúcich v tomto meste absolvoval v rokoch 1962 - 1965. Následne študoval na Právnickej fakulte Univerzity Komenského v Bratislave (1965 - 1970). V hlavnom meste zotrval (od roku 1970); rok bol právnikom na Generálnom riaditel'stve Slovenských energetických podnikov (1970 - 1971). Dva roky (1972 - 1974) pracoval aj v Slovenskom zväze bytových družstiev a neskôr vo vydavatel'stve Slovenský spisovatel' (1975 - 1980). V d'alšom decéniu pôsobil ako spisovatel' z povolania (1981 - 1990). Od roku 1990 bol tri roky opät' právnikom na mestskom súde a od roku 1993 právnym expertom Najvyššieho kontrolného úradu Slovenskej republiky. V súčasnosti žije na dôchodku v Bratislave.

Habajove ,vážnejšie‘ literárne texty, v ktorých často až jedinečným spôsobom zobrazuje minulost' i súčasnost' slovenského juhu, začali vznikat' začiatkom sedemdesiatych rokov. Dôkazom toho sú prózy Dolniaci (1972) i poviedkový súbor V tieni moruše (1973; za ktorý bol odmenený Cenou Zväzu slovenských spisovatel'ov). Obe knihy sa tematicky viažu k južnému Slovensku, teda ku krajine autorovho detstva. Šest' próz, zahrnutých do zbierky Mária (1976), predstavuje kultivovaného rozprávača, ktorý dôkladne pozná problémy súčasného človeka, usiluje sa ich riešit a nájst' pritom východisko. Jednotlivé novely spája nielen istá tematická jednota, ale aj dostredivý hodnotiaci pohl'ad na samotnú l'udskú existenciu. Hrdinovia bilancujú a retrospektívne sa zamýšl'ajú nad svojim osudom a konaním. Pre deti a mládež Habaj publikoval poviedkovú knihu Vel'ké stepné vtáky (1977), v ktorej Peter, chlapec z mesta a jeden z hrdinov knihy, chodí počas prázdnin $\mathrm{k}$ starému otcovi a tetke do dedinky pri Dunaji. Každé leto je pre neho novým dobrodružstvom; rád navštevuje strýka a jeho zázračnú záhradu, kde všetko dozrieva prv ako inde. Sníva o tom, že raz sa mu podarí uvidiet' tajomné, avšak pre južné oblasti Slovenska typické stepné vtáky - dropy. Šest' próz, ktoré autor zhrnul do zbierky noviel a poviedok Pol'né samoty (1979), predstavujú myšlienkovo podobné črty s jeho predošlými knihami. Nezastiera v nich tragiku l'udského života; takmer v každom texte však demonštruje nové dimenzie vztahohov, hl'adá riešenie konfliktov, l'udí a myšlienok. Životné osudy jednotlivcov z pol'ných samôt tak dostávajú spoločenský ráz. V knihe Posolstvo detstva (1982) konfrontuje dva životné postoje - proti l'ud'om, ktorých hlavným alebo jediným ciel'om je hromadenie majetku a iných vonkajších znakov životného úspechu, stavia jednoduchých pracujúcich, ktorí nikdy nestrácajú zo zretel'a mravné a l'udské hodnoty a úprimne si želajú, aby život nebol iba blahobytnejší a pohodlnejší, ale aj čistejší a spravodlivejší. Zaujímavá je zbierka próz Sedem poviedok (1984), ktorej hrdinovia sú napospol l'udia dnešných dní; tí, ktorí pochádzajú zo sociálne slabších vrstiev, prevažne z prostredia pracujúcich. Súbor poviedok Vône podbránia, vône bylín (1986) možno charakterizovat' ako psychologicky ladenú galériu postáv, postihnutých samotou, izoláciou, rozčarovaním, ale aj silným kritickým postojom k morálnej vlažnosti okolia - najmä príbuzných a mladšej generácie. V súbore poviedok Bezradnost' náhlej osamotenosti (1988) autor opät' piše o osudoch starších l'udí z postupne sa vyl'udňujúcich osád južného Slovenska, pričom 
ich sleduje zväčša v pochmúrnych osudoch plných protikladov, bolestí, nesplnených očakávaní i sklamaní, ktorí silou pevnej vôle zápasia proti nel'ahkému osudu. Po zmene režimu sa na pultoch kníhkupectiev objavila kniha Zo života outsiderov (1991). Literárny počin autora v tomto texte zaujme čitatel'a predovšetkým odvahou pozriet' sa na odvrátenú, neraz tabuizovanú stranu doby. Osudy l'udí, poznačených úsilím o prekonanie spoločenskej krizy z konca šest'desiatych rokov, sa dotýkajú najpálčivejších miest našej nedávnej historickej skúsenosti.

Ako akési ,dokreslenie' autorovho portrétu uved'me, že viaceré jeho prózy boli preložené do bulharčiny, češtiny, mad'arčiny, nemčiny, pol'štiny a ruštiny, d'alšie vyšli v antológiách slovenskej prózy v zahraničí, resp. vo vlastnom výbere s názvami Príbuzní z ostrova (1978) či Návraty (1987).

Z uvedených biografických i bibliografických údajov je evidentné, že Ivan Habaj je integrálnou súčastou slovenského literárneho kontextu. Svojimi prózami dôkladne poukázal na typické črty, atribúty a charakteristiky južného Slovenska. V jeho umeleckom zobrazení sú zaujímavé (aj) postavy, ktoré nesú v sebe pečat' doby, okolia, vztahov a mentalít. S určitým úškrnom sa však k tejto stránke Habajovej prózy vyjadril Valér Mikula ako ,Observátor IV“, vyslovujúc myšlienku, že „Habajove archetypálne postavy, ktoré majú vzbudzovat' úctu, robia z neho vari nášho najatavistickejšieho spisovatel'a..." (Observátor IV 1981, 95). Celkovo však môžeme uviest', že jednotlivé l'udské charaktery v prozaickej tvorbe Ivana Habaja reprezentujú vždy čosi viac ako sami seba. Autor vedome zdôrazňuje na nich tie atribúty, ktorými sa pripútali k nadosobnému celku. Habaj je preto „racionálny typ prozaika, čo má svoje prednosti, od formulácie problémov, cez štýl, fabuláciu až po kompozíciu..." (Petrík 1982a, 7). Na určitý vrcholok nášho ,slovenského literárneho Parnasu dospel najmä vd'aka tematike slovenského juhu, ktorá sa (aj) jeho zásluhou stala teritoriálne i kultúrne integrálnou, i ked', pochopitel'ne, okrajovou oblastou slovenského literárneho centra. (Nezabúdajme pritom ani na literárnu tvorbu Petra Andrušku a Ladislava Balleka!) Ako zobrazovatel' dediny však zostal tradičný, ba priam tradicionalistický; jeho autorská vývinová cesta je tak ,„priamočiara, takmer systematická. Jeho novely sú v námete i tvare vlastne pripravou k románu, v ktorom vrcholí jeho spisovatel'ský vývin“ (Kochol 1982, 108).

Významným medzníkom (až syntézou) v literárnej tvorbe Ivana Habaja bolo publikovanie trilógie Kolonisti I (1980), II (1981), III (1986). Tento rozsiahly - až skoro devät'stostranový - text je možné chápat' aj ako beletrizujúci doplnok dejinného pohybu, udalostí a ich vplyvu na jednotlivé rodiny. Autorov zámer bol pritom aj v zobrazení spoločenskej dynamiky pri uvádzaní protirečení národnostných zrážok. Jeho obraz je umeleckým preniknutím k zložitej problematike tejto skúsenosti. Presvedčivo a presne kreslí postavy a ich morálne podoby - najmä z ich činov a prejavov. Vztahy nechápe ako obnažené a schematizované hybné sily, ale ako javy, ktoré prestupujú celú spoločenskú štruktúru v konkrétnych individualizovaných činoch. Podáva tak „umelecký obraz toho, čím musel dnešný človek prejst', aby si do detailov uvedomil cestu nespočetných prekážok i rezíduí, ktoré treba prekonat' k skutočne plnému rozvoju“ (Truhlář 1981, 59). Habaj vykresl'uje l'udí na Žitnom ostrove, resp. zobrazuje skúsenosti niekol'kých slovenských rodín, ktoré prišli za obživou na tento úrodný kraj, ked' po prvej svetovej vojne Mad'arsko odstúpilo toto 
územie Československu. Po jeho rozpade (tzn. po Mníchovskej dohode) v roku 1938 pripadol Žitný ostrov opät' Mad'arsku a kolonisti sa museli stahohovat' naspät' na slovenské územie. Až po oslobodení, teda v roku 1945, ked' Československo opät' získalo toto územie, sa kolonisti mohli vrátit'.

Dielo je vlastne trilógiou, historicko-spoločenskou prózou; český literárny vedec Karel Brušák ho pomenoval dôležitým a originálnym románom. Prvá čast' časovo pokrýva väčšinu roku 1938, kým prechádzajúca história kolónie a niektorých jej obyvatel'ov je načrtnutá retrospektívne - čiastočne rozprávačom, ale najmä spomienkami jednotlivých postáv. Druhá a tretia čast' je venovaná obdobiu po druhej svetovej vojne, od návratu kolonistov na Žitný ostrov cez kolektivizáciu pol'nohospodárstva až do roku 1965. Medzi prvým a druhým zväzkom je časový odstup asi sedem rokov. Zo života postáv sa v tomto intervale celkovo odhal'uje len vel'mi málo; o udalostiach počas týchto rokov autor nehovori takmer nič.

Trilógia má predovšetkým charakter triezvej a autorsky neosobne vyjadrenej (azda rol'níckej) kroniky, v ktorej historický rámec predstavuje akési príležitostné pozadie. Je to vlastne - v určitom zmysle slova - „regionálny román sústred'ujúci vel'a pozornosti na sily, ktoré determinujú identitu regiónu tým, že ho izolujú ekonomicky aj kultúrne. Ako sa román rozvija, regionálne pozadie sa stáva metaforickým a vypovedá viac o postavách, ktorých charaktery sa pod vplyvom nového prostredia zmenili“ (Brušák 1988, 58). Približuje sa tak k tzv. románu o pôde, zaoberajúcemu sa bojom s prírodou a ospevovaním spôsobu rurálneho života. Tieto prvky konštituujú jeho mytologickú stránku a evokujú zobrazenie času, večnosti prírody a pominutel'nosti človeka. Uvedením mad’arskej menšiny, žijúcej na tomto území, sa dielo približuje aj k tzv. etnickému románu. Autorovo riešenie národnostných problémov je však napriek evidentnej historickej konfliktnosti v podstate harmonizujúce; problém vidí najmä v politickej rovine, ovel'a menej v pozícii človeka-jednotlivca.

Spisovatel' je tesne spätý s daným chronotopom. Dôležité je pritom identifikovat' jeho vlastný autorský idiolekt. V pozadí toho môžeme uviest', že Habaj pozoruhodne píše o tom, čo dobre ovláda: „Postavenie kolonistov poznám aj z rodinných vztahov, presnejšie, viem si ich domysliet' - zažil som ešte generáciu svojich rodičov i starých rodičov, tú pôvodnú generáciu, ktorá všetko brala tak trochu s úsmevom, uvedomovala si relatívnost' toho všetkého, uvedomovala si aj dejinnú nevyhnutnost' a vedela sa skôr nad udalostami zasmiat"“ (Habaj 1982, 25). Pri tvorbe Kolonistov autor však nemohol vystačit' len s osobnou skúsenost'ou. Napriek tomu, že berie do úvahy rovinu textu, dôsledne neanalyzuje spoločensko-historickú skúsenost', ale snaži sa identifikovat' osud človeka, ktorého tieto udalosti zasiahli. Rozprávač sa pritom s postavami stotožňuje a súčasne ich núti mat' integrálny pohl'ad na svet. (Vidíme tu príbuznost' s autorovou krátkou prózou.) Zámer Ivana Habaja, ktorého plnokrvné a zemité diela znamenajú trvalý prínos pre slovenskú literatúru, spočiva aj vo vytvorení verného a umelecky presvedčivého miestopisu Žitného ostrova v uvádzanom oblúku desat'ročí. Jeho úsilie tak bolo vytvorit' román „o tom všetkom, ktorý by ponad regionálny povrch presiahol do všeobecnejšieho zmyslu, ktorý by však obsiahol aj nové poznanie slovensko-mad'arského vzt'ahu..." (Hajdani 1986, 6).

Podmienkou d'alšieho spoločenského rozvoja - $v$ pozadí sujetu románu - je všestranná (teda aj kultúrna) vyspelost' človeka. Otvárajú sa pritom dost' široké 
priestory, v ktorých literárny text môže plnit' špecifické funkcie: silou a pritažlivostou slova pôsobit' na l'udí, prebúdzat' v nich vôlu a chut' do života, robit' ich prístupnejšimi k dobru. Naučit' ich spolucítit', navzájom sa inšpirovat', nadchýnat' široké vrstvy pre spoločné ideály, pomáhat' im nachádzat' odpovede na otázky, ktoré ich neraz trápia a mýlia, prispievat' a uvedomovat' si svoje miesta a postavenia po vlastnej ohraničenosti sveta. Tak, ako sa to pokúša aj Ivan Habaj vo svojej trilógii.

Pre tohto prozaika, ktorý svoje detstvo prežil najmä v komárňanskom okrese, je istou devizou fakt ,empirického poznania získaného z viacerých zamestnaní a zažitie dedinského i mestského prostredia. Južnoslovenská krajina s jej osobitostami a kontrastmi ho priam podnecovala k prozaickej výpovedi“ (Vel'ký 1984, 5). ,Rovinné prózy sú v zhode nielen s geografiou kraja, ale i so zvrásnením tvorivého srdca autora. Ako sa sám vyznáva o rovine, ktorá ,je pre mňa chrám, kde mám šancu očistit' sa od hriechov svojej človečej samol'úbosti. Tu dolu cítim sa byt' naozaj vo svojej koži, zdá sa mi, že i tie zákonitosti života si práve tu uvedomujem intenzívnejšie, než kdekol'vek inde [...] Povodeň v šest'desiatom piatom roku som prežil v osade Okánikovo, na skok od pretrhnutej dunajskej hrádze pri Číčove" (Svetoň 1992a, 3). Krajina južného Slovenska a l'udia, ktorí v nej žijú „,predstavujú pre mňa jednotu, v ich vzájomnej spätosti nachádzam tie vzrušujúce impulzy, ktoré ma ako autora i ako človeka nenechávajú l'ahostajným“ (Kamenistý 1981, 6). Ďalej k tomu Ivan Habaj dodáva: „už odvtedy, čo som v útlom veku začal poznávat' svet, vnímal som rovinu ako dramatický priestor. Preto som doma práve tam [...] Môj starý otec bol z generácie legionárov v Rusku, ktorí tam prešli kalváriou a po niekol'kých rokoch sa cez celý svet dookola vracali domov na Slovensko, kde sa on stal kolonistom. Moja matka je tiež z tejto kolonistickej vetvy. Ja som sa narodil na Ponitrí, tam, kde cez vojnu boli kolonisti odsunutí. Po vojne sa mnohí na svoje majetky na juhu vrátili, najprv väčšinou tí starší, neskoršie prišli aj moji rodičia so mnou. Takže vlastne už od malička som počúval o histórii kolonistov. Najdôležitejšie teda bolo prežitie detstva v tomto kraji, priestore, ktorý je univerzálny, všel'udský bez ohl'adu na národnost"“ (Svetoň 1992b, s. 2). V tomto chronotope som sa „cez bunky a gény svojho predka po prvý raz zoznámil s krajom rovným ako stôl, obkoleseným riekami, s krajom topol'ových vetrolamov, agátových lesíkov, osamelých listnáčov roztratených kde-tu po obilných lánoch..." (Habaj 1981b, 6).

Ked' bola v roku 1919 uzákonená pozemková reforma, pohýnajú sa zo severnejších oblastí Slovenska dolu k Dunaju tisícky slovenských l'udí. Zo zobratej pôdy si kupujú pri južnej hranici republiky pridelený kus zeme. Zväčša na území dnešného komárňanského okresu vznikajú kolónie: Horná Zlatná, Mudroňovo, Okánikovo, Šrobárová, Štúrová, Violín a iné. Najväčšou kolóniou bolo Hodžovo, ktoré po vojne premenovali na Lipové. V týchto kolóniách boli zväčša kolonisti z územia medzi Bánovcami nad Bebravou a Trenčianskymi Teplicami. Menšia čast' z nich prišla z východu, možno desat' percent, a azda desat' až pätnást' percent boli Moravania, sem-tam jednotlivci z Oravy a Kysúc. Osady pritom neboli vel'ké: Lipové bola jednou z najväčších osád kolonistov, kde žilo spolu 78 rodín. V Okánikove okolo 30 rodín, v Štúrovej okolo 20 , vo Violíne rozptýlene na samotách okolo 50 rodín. Na slovenské pomery to boli teda malé dediny. Pars pro toto o nich píše Ivan Habaj vo svojej trilógii. Ich obyvatelia verili, že si na Dolniakoch zarobia na väčší krajec 
chleba. Zakladajú osady-kolónie, trpia chorobami či nedostatkom, ale pomaly sa zmáhajú. Niektorí sa v prvých rokoch vzdávajú, iní sa po prekonaní začiatočných tažkostí zživajú s novým okolím, splácajú pôžičku, kupujú nové stroje, rozširujú polia. No tento život - pripomínajúci túžbu l'udí po zasl'úbenej zemi - sa náhle prerušuje. Po siedmich rokoch (po skončení druhej svetovej vojny) sa kolonisti opät' vracajú na Žitný ostrov, no nachádzajú tam málo z toho, čo zanechali. Domy sú spustnuté, zničené, ich prechodní obyvatelia vytínali agáty, ovocné stromy, zvál'ali ploty. Skoro vo všetkom je potrebné začat' odznova...

Jeho prózy zavádzajú väčšinu čitatel'ov do nového, literárne dovtedy nevel'mi zmapovaného prostredia: do kraja pšenice, kukurice, melónov, dyne, papriky... Ved' ako sám autor píše: „moja ústredná diel'ňa leži ešte stále tamdolu. Priznávam sa k tomu ešte raz, hoci sa mi vidí, že takto, na prvé počutie, slovenskému uchu moje priznanie býva i podozrivé [...] A veru aj to ma, okrem iného, utvrdzuje v názore, že nejeden z príslušníkov národa, ku ktorému patrím, vie toho málo o tej čiastke svojej domoviny, ktorú predstavujú rovinné šíravy nad Dunajom" (Habaj 1980b, 1). Vnímaví čitatelia sa tak postupne môžu zoznamovat' so zaujímavými, neraz pohnutými osudmi tamojších l'udí. Ako to sám Habaj uvádza: „Na väčší románový cyklus som myslel už na začiatku tvorby. Ale až po napísaní Márie (t. j. zbierky šiestich poviedok z roku 1976 - pozn. P. Š.) som získal presvedčenie, že ho treba napísat' [...] Preštudoval som dokumentárne materiály, ponáral som sa do problematiky doby pred mojím narodením, až som získal pocit, akoby som v nej žil. Vel'a som sa dozvedel aj od môjho starého otca, od rodičov a d'alších l'udí z tohto kraja. Nebola to pokojná doba, zo dňa na deň sa všetko menilo, bolo sa treba v tom zorientovat'. Nemala to byt' len čistá beletria, ale aj dokumentárna próza, v ktorej by fakty zostali hodnoverné a v tom až úderné" (Mikolaj 1983, 8). Habajova próza je tak „poctou generácii, ktorá v živote vždy vyznávala pevné hodnotové kritériá“ (Borčin 1987, 4). Text tak v čitatel'och upevňuje aj morálne kritériá, l'udskú i spoločenskú súdržnost' a životnú perspektívu. V trilógii čas osciluje v rovine: čas historických udalostí - čas diela - čas postáv. S jej vnútornou štruktúrou súvisí „,celkový čas diela, tzv. makročas a jeho atomizácia, t. j. vnímanie tohto času postavami prózy - mikročas. Čas historických udalostí je objektívne daný, existuje nezávisle od času prózy a s jej vnútornou štruktúrou začne súvisiet' až vtedy, ked' sa premietne do makročasu i do mikročasu“ (Fazekašová 1983, 147). Existuje však úzka súvislost' medzi časom postáv a historickými udalostami: navzájom sa prestupujú, pričom takmer vždy ide o vyrozprávanie dramatickej historickej doby prostredníctvom osudov l'udí v nej. Ono sa uplatňuje v dvoch líniách: subjektívne, t. j. v preživaní fiktívnych postáv a objektívne, ked' autor akoby mimo fiktívneho deja informoval autenticky, objektívne o historickej udalosti, uvádzal stáa kronikársky sled súvislostí a okolností. Historické deje pritom majú nezastupitel'né funkcie: tvoria súradnice rozprávania a rámec pre konanie postáv. Na základe toho celkový čas diela je určovaný dvoma faktormi: lineárnym plynutím historického, spoločenského času, ktorý tvorí koordináty rozprávania a lineárnym plynutím rozprávačského času. Celkový čas diela sa tak realizuje $v$ pásme rozprávača aj v pásme postáv. Základnú líniu postáv môžeme nazvat' tzv. kalendárovým časom. Je to reálny čas postáv, v ktorom je obsiahnutý zmysel ich života a primknutosti k zemi, zdôraznená prirodzeným strie- 
daním ročných období. Habaj modeluje ideový svet svojej prózy v pozadí opozícií staré - nové, minulé - prítomné, svoje - cudzie a spoločenské - individuálne. Trilógia sa tak stáva „syntetickým vyrovnávaním sa autora s minulostou, s problematikou histórie v špecificky regionálnom i národnostnom, na konflikty bohatom prostredi“" (Kapsová 1988, 109). Je to priestor s prítomným spoločenským aspektom, ktorý je však tlmene pod povrchom vonkajšieho pribehu; spoločenské sa tak stáva pozadím onoho individuálneho. Mierou takéhoto kontrastu autor zvyšuje expresívnost' a emocionálnost', čím podmieňuje špecifickú estetickost' (a percepciu) textu. Dominantnou črtou celej kompozície trilógie je tak „,premyslená autorská stratégia v makrokompozícii, opierajúca sa o preferovanie kauzálnych vztahov pred priehl'adným preferovaním časovosti pribehu. Časovost' v Habajových Kolonistoch je však zrejmá a hrá síce sekundárnu, ale predsa dôležitú úlohu“ (Čúzy 1986, 118). Jednotlivé kapitoly majú pritom dvojakú štruktúru: začínajú detailnou kresbou prostredia a atmosféry či akčnejšou charakteristikou postavy, ktorá vstupuje do epizódy začínajúceho pribehu. Ich jadro má vždy minuciózne dejový charakter v pozadí konkrétnych spoločensko-historických faktov, ktoré sú tak dôležitým pozadím pre konanie postáv.

V Kolonistoch identifikujeme pevné pocitové a zážitkové zázemie detstva i presah individuálneho do sociálno-národného zážitku. Ono má predpoklady odhalit' akúsi tragiku južnoslovenského prostredia nielen v nostalgickej, ale aj dramatickej podobe. Detaily pritom prekonávajú sústredenost' na konflikt a stereotypné kompozičné schémy; rozširovanie pohl'adov či dôraz na pribeh a jeho kronikárske zachytenie nesú v sebe viacdimenzionálne interpretačné možnosti. Životné pribehy kolonistov - akoby paradoxne - dostávajú spoločenský kolektívny rozmer, ktorý pomáha prekonávat' osamotenost' i nepriazeň obdobia. Individuálne osudy sa podriad'ujú osudom celku. Autor tak (aj) pri zobrazení vztahov dospel „,k syntéze, ktorá má vedome ráz umeleckej, ale svedeckej výpovede, jedinečnej historicko-spoločenskej rekonštrukcie, ktorá transformuje individuálne do celospoločenského“ (Chmel 1981, 112).

Opät' je dôležité zdôraznit', že prítomné rozprávanie v trilógii opisuje udalosti jedného až dvoch rokov, pričom zakaždým je to obdobie, v ktorom sa začinajú tušit' a prejavovat' prudké sociálne zmeny a pohyby. V prvej časti je to rok 1939 , v druhej roky 1945 - 1947, v tretej roky 1964 - 1965. Retrospektívy postihujú roky dvadsiate i tridsiate, obdobie druhej svetovej vojny a kolektivizácie. Vol'bou tejto kompozície autor dopredu limitoval dramatické pôsobenie textu, ale vyjadril sa aj o konkretizácii (a domýšl'aní) sujetu: „Sám cítim potrebu vo svojich Kolonistoch niečo dopovedat' [...] Ĺudia, o ktorých píšem, tu už poväčšine nežijú. Ale krajina zostáva (Mikolaj 1983, 9). Tá konkrétna, južná, má, ako sme to už uviedli, u Habaja dôležitú funkciu, ved’ badat' u neho ,aj istú jej glorifikáciu, ktorá sa premieta i do lyrizácie výrazu“ (Gombala 1980, 5). Dôležitá je však pre neho aj možnost' uvádzat' krízové deje s odstupom, ponúkajúcim väčšiu objektivitu a komplexnost' obrazu; svedči to aj o ciel'avedomom a zodpovednom autorskom prístupe k téme. Významná je pritom aj symbolika: meno Lipová Osada, v ktorej sa pribeh centrálne odohráva, vyjadruje československost'; lipový list je československým symbolom: Habaj sa ním pokúša obohatit' (aj) slovenskú národnú mytológiu, pričom s tretou 
častou naznačuje akýsi uzavretý pribeh. Komplexnou prednost'ou trilógie je pritom jej „,ideová vyhranenost', silný humánny étos, vnútorná angažovanost', úcta k odkazu predkov a nemalá slovesná kultúra“ (Machala 1989, 55). Badat' pritom Habajovo permanentné úsilie sústredene „umelecky stvárnit’ južné Slovensko v jeho zložitej, ale osobnostne i vel'mi jednoduchej podobe..." (Obuch 1986, 4). Tak sa trilógia koniec koncov stáva umeleckým obrazom toho, čím musel človek danej doby prejst', čo všetko zažil, aké rezíduá musel prekonat', aby vybudoval spravodlivý (ba spravodlivejší) svet, aby sa cítil plnoprávnym občanom a aby bol schopný pochopit' aj to, čo kedysi zapríčiňovalo jeho utrpenie. Sila tohto diela tak spočiva $v$ tom, že „bez postranných a pomstivých línií zobrazil objektívne skutočnosti a umelecky spoliehajúc sa na realizmus, na pravdivý dejinný vývin [...] je uceleným a závažným svojou evokáciou dejinnej pamäti“ (Truhlár̆ 1987, 5). Habaj svojimi Kolonistami „obdaril hodnotové bohatstvo našej súčasnej prózy d’alším vel'kým, zrealizovaným epickým projektom, ktorý má svoje dosahy spoločenské, kultúrne, národné a literárne. Predovšetkým tematickou a látkovou rozložitost'ou a ich historicko-epickou syntézou“ (pš 1987, 1). Vytvoril tak dielo kompaktné a jedinečné, ktoré priekopnícky prispieva k analýze a identifikácii vlastných národných i stredoeurópskych dejín, a je tak markantným prínosom pre vývin slovenskej prózy.

V roku 1980 v renomovanom vydavatel'stve Slovenský spisovatel' vyšiel prvý zväzok trilógie - teda Kolonisti I, za ktorý Ivan Habaj získal Cenu Zväzu slovenských spisovatel'ov (JUDr. Ivan Habaj 1983, 4). Bolo to t. č. prekvapujúco ,nové dielo so spoločensky závažným námetom. (Ako určitú zaujímavost' uved'me, že v rámci pravidelných utorkových kritických diskusií na sekretariáte Zväzu slovenských spisovatel'ov 13. januára 1981 uskutočnila Komisia pre teóriu a kritiku ZSS diskusiu o románe Ivana Habaja Kolonisti I - Diskusia o Habajových Kolonistoch 1981, 159.) Autor v ňom zobrazil bolestnú dejinnú kapitolu v živote slovenského človeka, pričom využil určitú komunikatívnost', ktorá „,vyplývala z poznania sociálnej typológie, krajinného prostredia" (Truhlář 1982a, 19; slová samotného Břetislava Truhlářa). Prvá čast' trilógie naznačila intenzívnejší presah individuálneho zážitku do sociálno-národného a historicko-politického skúsenostného kolektívneho komplexu, ktorý poskytoval autorovi bohatý, pestrý i dramatický materiál, v ktorom sa zrkadlí individuálna i kolektívna skúsenost', zápas o dôstojnost' a št́astie jednotlivca či tragika celého spoločenstva. Tak sa tento text stáva generačným úsilím pri hladaní koreňov domova i zavŕšením autorových osobných ambícií pri zobrazení prostredia a postáv jeho ,príbuzných z ostrova'. Ústredný konflikt sujetu má pritom spoločenský charakter; konflikty „sú hlboko ponorené do l'udského portrétu, do jeho vlastností i konaní“ (Truhlář 1985, 88). Národnostná problematika, ktorá sa prejavuje v zrážkach, však spôsobuje, že spoločenský konflikt sa postupne presúva do konfrontácií názorov jednotlivých osôb. (Uvedenú skutočnost' nejakým spôsobom zažilo aj celé národné spoločenstvo, pretože sa dotkla citlivých strún jeho ,južnoslovenského' vnútra a dnes tvorí neoblomnú súčast' jeho historického vedomia.) Ivan Habaj neskrýval, že napriek zdanlivému pokoju poprevratového spolužitia, v uvádzaných časoch opät' vznikali spory i zrážky.

Aj z týchto dôvodov pribeh kolonistov na južnom Slovensku musel niekto napísat'. Napísal ho ten, koho sa to osobne dotklo. Ten, kto dôkladne pozná svoju 
tému „,zvonku i zvnútra. Aj ked’ sa korienkami pamäti drží najmä rodinnej skúsenosti, rozširuje ju na všetky strany, aby mohol vypovedat' o celom výseku historickej skutočnosti“ (Petrík 1982b, 6). Habaj sleduje život kolonistov vo všetkých troch rovinách, pričom sa najviac venuje prvej (kolonizovanie pôdy), pretože chce vzkriesit' svet, ktorý v premenách času už zanikol, a tak mu to diktuje aj samotný životný materiál. Spomínaný nacionálny moment vstúpil do popredia v druhej polovici prvej a v úvodných častiach druhej časti, no tam sa tažisko postupne presúva k sociálnemu faktoru.

V Kolonistoch I sa hovorí o slovenských l'ud'och, ktorí „prišli z horných kamenistých krajov dolu k Dunaju, s pieskom zaviatym hrobom dávnych predkov, aby tu, na južnom okraji založili osady, aby si tu, v pote, odriekaní, dorobili väčší krajec chleba, aby si tu založili rodiny a rody, aby tu hájili svoje právo na prosté l'udské št'astie“ (jf 1981, 5). Za čas udalostí v románe Kolonisti I si teda Habaj zvolil koniec tridsiatych rokov, kedy sa sociálne, politické a národnostné konflikty na južnom Slovensku začali vyostrovat'. Kompozičný prstenec je pritom realizovaný scénami, v ktorých sa protagonista Peter Jakubec zdržiava v osadníckom cintoríne: v úvode tu pochováva svojho mladšieho brata, v závere, odchádzajúc z Lipovej Osady, sa na tomto mieste lúči so zosnulou manželkou. Vidí pritom protirečenia individuálnej, sociálnej a politickej povahy. Habaj odkrýva praktiky vel'kostatkárov a rozmach po prevrate, ked' sa zem dostala do rúk nových vlastníkov. V polovici románu do rozprávania výraznejšie začínajú prenikat' prvky napätia: cez kriminálnu zápletku okolo vraždy či prostredníctvom udalostí súvisiacich so známost'ou s mad'arským chlapcom. Ĺudia sa postupne uzatvárajú do seba, menej si dôverujú; román je na týchto miestach aj psychologickou štúdiou ohrozeného kolektívu, ,snímanou však cez jednotlivcov. Postavy sa v závere zmietajú v prudkých výkyvoch medzi neistou nádejou a silnejúcim tragickým pocitom skutočnosti. Na hranici sa rozmáha násilie, teror a podpal'ačstvo. Zaujímavý (ba symbolický) je pritom paralelne sa klenúci prírodný motív, ved' v prvej časti trilógie „vedie od ned'alekej stanice agátová alej, ale počas mad'arskej okupácie cez vojnu agátový les zotnú. Obraz vytatého agátového lesa tvorí refrén v druhých dvoch častiach trilógie“ (Pynsent 1989, 80). Román sa uzatvára udalostami, ked' sa celá rodina stahuje na sever a má sa usadit' na Ponitrí, kde je možné začat' odznova. Tamojšie obyvatel'stvo však prijima kolonistov nepriatel'sky, ved' samo zápasí s nemalými sociálnymi tažkostami a nie je ochotné delit' sa ani o existenčné minimum. Udalosti pritom poukazujú na sociálne procesy pri zvolenom prostredí a sú zároveň aj vonkajším indexom vnútorných individuálnych aj kolektívnych preživaní. Hodnota textu en bloc je aj v tom, že „prepojenie medzi javovým a podstatným, povrchovým a híbkovým nehl'adá spisovatel' cestou výslovnej formulácie $v$ autorskom komentári, ale tým, že núti prijemcu domýšl'at' zmysel epických dejov a nachádzat' ich skryté súvislosti“ (Bagin 1981, 42).

Habaj pracuje s istotou v rozprávaní aj v opise; opiera sa o skúsenosti slovenskej sociálnej a lyrizovanej prózy, hoci sám nelyrizuje. Týka sa to aj kolonistov, ktorí sa musia vyrovnat' s nezvyčajne rýchlo sa meniacou realitou - a to skôr v činoch ako v myslení. $V$ ich konaní sa pritom poukazuje na vyhranené hodnotové postoje, ktoré tvoria budúcnost', práca, rodinné vztahy, voda, zem. Obsahom ich bytia je však najmä práca na pôde a úsilie vydobyt' si úrodu (aj napriek živlom). Habaj 
tak opisuje svet, ktorý „,tisícom drobných bezmenných l'udí, rol'níkom, bezzemkom, bírešom a to rôznych národností, pomohol k tomu, že konečne začali nadobúdat' svoju l'udskú dôstojnost'! Odstránil tiež sociálnu nerovnost' medzi príslušníkmi rôznych národností, postavil l'udí na nohy i materiálne a dal im základné životné istoty. Ĺudia vystreli chrbát" (Gallo 1994, 11). Aj preto je dôležité väčšmi zvýraznit' to, čo je na celkovej tragike l'udských osudov univerzálne, všel'udské, nezávislé od národnostnej príslušnosti.

Hoci autor má historické udalosti a životné reálie usadlíkov dobre naštudované a oboje po vecnej stránke náležite interpretuje, v jeho románe tieto dve zložky nikdy nesplynú. Predsa je však potrebné vyzdvihnút jeho komplexné „úsilie zobrazovat' neštastie južného pohraničia $v$ období pred druhou svetovou vojnou [...] $\mathrm{V}$ tomto [...] je napokon aj humanistický zmysel Habajovho románu“ (Halvoník 1981, 6). Literárny vedec Viktor Kochol pritom nazval Ivana Habaja solídnym románopiscom, ktorý v každom ohl'ade vytvoril takmer dokonalý román s organicky podchyteným epickým vývinom, zaznamenávajúcim kvalitatívny skok vpred. Vo svojej trilógii Habaj prezentoval zrelý, cez sito racionálnej súdnosti precúdený umelecký artefakt. Hlavným príznakom jeho epickej zrelosti je pritom zobrazenie spoločenského objektu v jeho totalite. Desiatky kolónií, zväčša na predchádzajúcich statkárskych majeroch, vzniklo v prvom desat'roči československého štátu ako výspa československého živlu na národnostne zmiešanom prostredí; ako ukážka voči predchádzajúcemu polofeudálnemu hospodáreniu a pokročilejšej strojovej pol'nohospodárskej výroby. Boli to rol'nícke osady nového typu, otvorené voči bližšiemu i vzdialenejšiemu svetu. Verejný, štátny záujem sa tu preplietol so súkromným, rodinným, individuálnym úsilím. Vznikol tak román, ktorý je obrazom celku, pravda, zredukovaným na typické črty a časti. Je to dielo o kolonistickom komplexe, nie partikulárny rodinný román; interné individuálne i rodinné osudy v ňom vystupujú v minimalizovaných vonkajších parametroch. Stavebným materiálom textu je čistý a „zredukovaný človek, bezmála zbavený svojho individuálneho vnútorného života, človek ako súhrn spoločenských vztahov - to je stavebný materiál Habajovho románu“ (Kochol 1981, 81). Rodinné a súkromné osudy autor pri svojich postavách síce tieňuje, no neprekresl'uje či neprehlbuje ich. Človek a jeho vnútorný život ho zaujíma len natol'ko, nakol'ko sa $\checkmark$ ňom prejavuje spoločenský celok. Ĺudský subjekt mu je len rámcom, z ktorého vychádza. Jednotlivé postavy tohto - možno nazvat' aj - kolektivistického románu vystupujú iba ako časti či zložky (nad)dedinského celku. S nejasnostou hlavného hrdinu ide $v$ románe ruka $v$ ruke aj absencia ústredného deja. Miesto vnútorného sujetu v ňom nastupujú vonkajšie diania a politické udalosti, ktoré zavalia usadlíkov Lipovej Osady, ostatných kolonistov i celé južné pohraničie Slovenska. Čas je teda dôležitý faktor, pričom: „Striedanie mikrozáberov a makrozáberov, kombinácia reprodukcie a opisu, prebiehanie z prítomnosti do minulosti je vizitkou zrelej a vybrúsenej autorovej epickej techniky..." (Kochol 1981, 84). Dejiny však vkročia do osady - kolonisti počúvajú rozhlas a čítajú noviny. V októbri - teda po Mníchove - je už jasné, že čast' južného pohraničia, predovšetkým kolonistický Žitný ostrov, pripadne Mad'arsku. Z usadlíkov sa zachraňuje, kto môže. V prvých novembrových dňoch československé úrady a armáda odchádzajú z pohraničia a územie okupuje mad'arské vojsko. Čast' kolonistov, ked'že nemá kde ist' ani evakuovat', ostáva 
na mieste a trpne očakáva svoj neblahý osud. Vyvrcholením toho sú tri záverečné kapitoly: prísne reprodukčné, maximálne mikrozáberové, ešte pochmúrnejšie ako úvodné (z cintorína). Tam zomrel ,iba' človek, v tomto prípade zomiera štátne a národné spoločenstvo. Habaj tu maximálne rozšíril makrozáber: prekročil empirické rozmery danej skutočnosti, povzniesol sa ponad ňu a uzrel, čo je za ňou. Rozšíril tým priestor i čas svojho empirického predobrazu a prekonal svoj reprodukčný i opisný zobrazovaci spôsob. Jeho obraz tak nadobudol charakter morálnej reflexie. Je to pozícia zobrazovatel'a a svedka; svedectvo však presvedčivé - má šírku, híbku, detail i pointu. Dielo pritom zobrazuje iba okrajovú čast' Slovenska, no v tejto časti sa vyjavuje celý národný celok; v jednotlivcovi sa spodobuje nielen spoločnost', ale v danej chvíli aj doba. Spoločenský čas však už vtedy začal pracovat' proti osadám kolonistov; vztahah rol'níka k pôde sa zauzlil. Po vojne prišla opät' chvíl'ka nádeje, ale potom nastali prudké sociálne zmeny, pohlo sa s majetkom a pôdou, odtrhlo sa čosi aj z vnútra človeka, zmenilo sa v dobrom i zlom a v premenách času začal zanikat' tento svet, ktorý už v starej podobe nebolo možné neskôr opät' oživit'.

Prvú čast' trilógie môžeme chápat' ako románovú epopeju, ktorá presvedčuje čitatel'a „o autorovej znalosti prostredia, krajiny juhu, l'udí, čo v nej žili. Zaujíma sa nielen o medzil'udské vztahy, ale aj o národné i nadnárodné udalosti, vykresl'uje situáciu v životnej akcii a rôznorodej konfliktnosti“ (Ďalšia románová epopeja 1981b, 6). O prvej časti tak možno hovorit' aj ako „o vernej freske vyše dvadsat'ročného historického úseku v tomto prostredí bohatom na búrlivé udalosti. Kniha je čitatel'sky zaujímavá pre epickú silu, hodnotnú plnú vetu, zaujímavé charaktery a živý dialóg" (-vv-1981, 59). Celkovo teda v nej autor prišiel s jasnou výhodou románovej témy, s vôlou a úmyslom „epicky zdokumentovat' často až dramatické, dejinne rozhodujúce deje na slovenskom juhu, kde konfliktné stretávanie sa národností nadobúdalo osobitne závažné dimenzie spoločenské i rovno politické“ (pš 1982, 6). Stretali sa dva etnické celky s rozdielnymi kultúrami, životnými pocitmi a svetonázormi. Popri tom národnostnú averziu na tomto rozhraní vyostrila koncom tridsiatych rokov aj politická situácia. Život ,na čiare' sa stal neraz životom násilia, zloby, útekov. V tomto pozadí: „Sujetovú osnovu koncipoval autor tak, aby dosiahol efekt typickosti - a to práve vzhl'adom na dvadsatročie existencie slovenských kolonistov na slovenskom juhu“ (Petrík 1981, 16). Zachytil tak kus hrdinstva obyčajného slovenského človeka, ktorému dal nový režim príležitost' a ktorý názorne predviedol, čo dokáže poctivá každodenná práca. Na jednej strane podotkol určitú diferencovanost' v názoroch (napríklad predstavitel'ov mad'arskej národnosti), na druhej strane pripomenul, že ani slovenská krajina neprijimala vracajúcich sa kolonistov s otvorenou náručou. Autor však má stále na pamäti svoj širší ciel': predstavit' v charakteroch (a príbehu) spoločenskú skupinu. Z týchto dôvodov sleduje skôr existenčnú ako existencionálnu stránku ich života, čím neuvádza príliš hlbokú sondu do ich najvnútornejšieho sveta. Historicky verné - a pritom živé a presvedčivé - osudy slovenských kolonistov na južnej hranici Slovenska chápeme cez toto dielo ako dôležitú súčast' osudov národného spoločenstva.

Ako sme už spomenuli, román sa začína obrazom vykopávania hrobu v cintoríne. Aj pri tejto práci sa zdôrazňuje symbolické spolužitie ,domácich a cudzích', ved' na tomto (zúženom) obdižniku zeme „,napokon postačí každému rovnako, skromné- 
mu i chamtivému, lotrovi i dobrákovi, Slovákovi, Mad'arovi, katolíkovi, luteránovi, ba i židovi“ (Habaj 1980a, 9). Bola to práve kyprá slobodná zem Žitného ostrova, ktorá prichýlila slovenských osadníkov, ktorí sa však postupne museli učit prispôsobovat' sa. Svedkom ich úsilia bol aj prastarý Dunaj, ktorý sa najsamprv ,,pozerá na nové l'udské pokolenie, ktoré sa práve hmýri na jeho brehu, ktoré sa s človečou trpezlivost'ou vzpiera nežičlivému osudu a verí, že práve ono nájde tu svoje miesto pod slnkom..." (Habaj 1980a, 14). Bodl'ačie sa postupne premieňa na mladú agáčinu, výhonky vystriedajú tŕnie - teda prichádza nový život. Kolonisti vysádzajú po oboch stranách ulíc lipovú alej. Slováci sa tak chtiac-nechtiac oboznamujú s južným koloritom okolia, ktorý Habaj opisuje čitatel'sky mimoriadne efektívne: „Južné slovenské pohraničie, územie tesne nad Dunajom, cestovný uzol, v ktorom sa od vekov stretávajú prúdenia rozličných kultúr, ale súčasne zem od stáročí nepokojná, búrlivá, neistá, presiaknutá krvou mnohých l'udských generácií, miesto vojnových stretnutí rozličných proti sebe idúcich mocenských útvarov, územie na ktorom odjakživa bolo málo pokoja, kde usadlíci ustavične museli s kýmsi bojovat', húževnato si bránit' holé životy a skromné chalupy, odrážat' útoky, prepady, plieniace nájazdy“ (Habaj 1980a, 13). Pri ich postupnom zabývaní sa je zaujímavé sledovat' aj ich výpovede, do ktorých sa po príchode do nového životného priestoru zamieša aj nejedno nárečové slovo. Lipová Osada je v tomto časovom úseku vlastne metonymiou chaosu a nedočkavosti poprevratového obdobia. Centrálnou istotou je však úrodná zem slovenského juhu. Autor pritom opisuje pokoru a racionálnost' Slovákov pri nadobúdaní hmotného majetku (zo štátnej pôžičky). Prídel rolí je základným odrazovým mostíkom nachádzania istoty na Dolniakoch, pričom prvé roky (spolu)naživania sú obzvlášt' tažké. Horniacke zvyky slovenských rol'níkov sa miešajú s dolniackymi tradíciami, pričom sa opät' zdôrazňuje potreba mierovej kooperácie a budovania novozaloženej obce. U staršej generácie je táto interakcia, pochopitel'ne, problematickejšia, avšak v prípade mladých nadviazanie priatel'stiev ide jednoduchšie, najmä pri nádenníckych prácach, žatve, mlatbe, zbere repy či kukurice. Kolonisti si pritom celkovo uvedomujú vlastný l'ahší život po prevrate, ved' bývalí bezzemkovia, bedári i drobní rol'níci sa zmohli a za svoju oddanost' republike dostali pôdu ako základný atribút svojho l'udskejšieho života. Ich osady boli nové, ved' l'udí v nich nezat'ažovala zdedená nevraživost' predkov a nezmietali sa ani v kŕčoch sociálnej nerovnosti. Vytvárali rovné (ba rovnaké) formy spolužitia. Takýmto spôsobom mohli kreovat' nielen symbolické, ale aj konkrétne železničné mosty so štíhlymi konštrukciami, smerujúcimi až k mad'arskému riečnemu pohraničiu.

Z nášho aspektu je zaujímavá aj alúzia na Komárno: spomína sa pevnost', futbalový štadión, jarmočnisko, kolónia Cigánov, katolícky i luteránsky kostol. Habaj pritom geograficky presne a historicky spol'ahlivo opisuje cestu z Lipovej Osady do Komárna, kde „hradská vyšla z úžl'abiny, vyštverala sa na hrádzu a po jej vrchole viedla asi kilometer, kým zasa nezišla dolu, aby potom úzkym podjazdom vedúcim popod mohutný železničný násyp vkročila na katastrálne územie okresného mesta, ktorého predmestie, množstvo bedárskych chalúp vytvárajúcich neusporiadané, krivolaké ulice, uzreli pocestní ešte predtým, než prišli k zvyškom stredovekej pevnosti, ukončeným mohutnou klenutou stavbou s obrovskými zdvojenými trojkrídlovými vrátami, nazývanými Bratislavská brána“ (Habaj 1980a, 59). Popri tomto 
geografickom atribúte autor spomína aj ned’aleké reálne osady či mestečká (často pod pseudonymami): Briežky, Lél, Lúky, Meder, Olšany, Svätý Peter, Tri Moruše, Veterné. Všetky tieto ,informačné bodky“ majú aj svoje epicentrá: krčmy, v ktorých sa pri rozhlase čaká na dobré i menej radostné správy. Vo vzduchu však visí nejaké historické šero, pričom každodenný život patrične pulzuje: pomocou Slovenskej ligy sa v dedine dokončuje budova školy. Kolonisti svoje okolie chápu ako akýsi kraj sveta, územie, miesto ,na čiare', za ktoré preliali aj krv a vybojovali tak republiku. Aj preto si svoj slovenský pôvod chránia, pričom dbajú aj na čestnost'. Konkretizáciou toho je proces parcelovania Lipovej Osady zememeračmi podla reguly. Identita kolonistov tak za dve decéniá, prežité na Žitnom ostrove, dostáva silnejšie kontúry, konkretizujúce sa aj v jednotlivých výpovediach: „Ja tu nie som dočasne, tu zostane po mne môj rod, do Lipovej Osady som neprišiel iba tažit' a zhrabúvat' bohatstvo, ja som tu zapustil korene, ja nikde inde nemám miesta!" (Habaj 1980a, 111). Napriek tomu sa však v pozadí celoeurópskych politických dianí aj nad Lipovou Osadou - pars pro toto - schádzajú temné mračná, pričom „čoskoro nato aj na hranici s južným susedom začali sa budovat' rôzne obranné zariadenia. Hustá siet' železobetónových bunkrov, mohutných, prakticky nedobytných pevností, doplnená jednoduchšími pevnôstkami, ktoré však plnili nemenej dôležitú úlohu ako ich obrovité sestry, tak dômyselne načrtnutá na strategických plánoch generálneho štábu, začala sa menit' na skutočnost"“ (Habaj 1980a, 107).

Konštantným symbolom južného koloritu je agát, ktorý vytvára akýsi idylický obraz každodenného života kolonistov: rastie pri chodnikoch a pol'ných cestách, múroch, plotoch, okolo samôt, majerov a cintorínov. Tieto stromy fyzicky i duševne pomáhali a pomáhajú Slovákom v tomto chronotope, ved' „húževnato, nepoddajne zachovávali svoj rod, aby potom l'ud'om lopotiacim sa v sparných dňoch na poli poskytli úl'avu v podobe vytúženého tieňa, aby im ponúkli svoje tvrdé kmene, použitel'né na kadečo, nielen na kurivo, a napokon, aby každoročne na rozhraní mája a júna, zahaliac sa do krehkého bieleho rúcha strapcovitých kvetov, zaplavili svet prenikavo sladkou vôňou, ktorú vánok zanášal aj na miesta, kde agát nerástol, takže ňou nakoniec skrz-naskrz nasiakol celučký kraj..." (Habaj 1980a, 130-131). Osadníci v tomto pozadí žijú svoj každodenný život, pravda, občas sa navzájom hašteria, avšak koniec koncov vždy tahajú za jeden povraz. Identifikujú pritom svoju existenciu na štátnej hranici akoby na trasovisku, pričom svoj pohl'ad i mysel' obracajú k republike. Dožadujú sa odstránenia rozdielov medzi Českom a Slovenskom v spojení s mad'arskými demokratmi (tzn. získat' menšinové masy pre republiku). V tomto motíve sa dá identifikovat' autorovo neustále úsilie o zmierenie aj v t'ažkých rokoch pred druhou svetovou vojnou. Samozrejme, aj v tomto období sa objavujú špekulanti, trasl'aví požierači pohraničnej línie, ktorí podstatnú čast' svojich ziskov neinvestujú do kolónie, ale do vnútrozemia republiky. Aktuálna politika sa tak dotkne aj tohto búrlivého kúta, do ktorej ,preniklo dost' a dost' neutešených správ o vývoji situácie vo svete, o postojoch západných vel'mocí pri rokovaniach s Hitlerom, o ich slizkej hadej koži, s ktorou sa im na trh íst' nechcelo" (Habaj 1980a, 182). Zlé správy sa postupne dostali až do psychiky kolonistov a privolali taživé ticho. Aktuálne vynesený rozsudok dejín len podopieral fakt, že „vo vel'kom hrnci, kde sa varí svetová politika, už zovrela voda na polievku, klokotala, bublala, syčala, 
z hrnca sa šírili rozmanité pachy..." (Habaj 1980a, 171). V tomto období klíčila nedôvera l'udí nielen voči cudzím, ale aj vlastným ako náznak trpkosti. Militarizáciou doby prichádza aj určité vyhranenie sa: radšej kolchoz, než Ríša či Svätý Štefan. Tento atribút sa vyostruje aj v žlčovitej škodoradosti kolonistov voči spoluobčanovi Petrovi Jakubcovi, ktorý sa vnútorne hanbí a odoláva vonkajším opovrhovaniam kvôli tomu, že sa mu dcéra vydala za Mad'ara. Okolie sa tak vd'aka spomínaným historickým udalostiam a osobným zrážkam stalo smutným, ba umierajúcim. Autor tento vnútorný pocit postáv v určitom zmysle slova kompenzuje efektívnym opisom krásnej nižinnej prírody, v ktorej sú „klasiská ako pol ruky, vozy kopcom naložené kukuricou, hŕby klasov naviršených v stodole, vence zlatožltej i tehlovočervenej kukurice na žŕdkach i kukuričné klasy natlačené medzi rebrami štíhlej sušiarne, koše omoržovanej kukurice a vedl'a nich horu bielučkých šúl'kov, predstavil si i pokojné dlhé večery na sklonku teplej jesene, presýtené vôňou čerstvého šúpolia, plné rytmického šuchotu, takého charakteristického pre obdobie, ked' sa šúpe kukurica [...] vstrebal do seba atmosféru pokoja, nasiakol vôňami slnkom prežiarenej krajiny, potešil si srdce i zrak rozmanitými odtieňmi teplých južných farieb, ovial ho vánok šírych rovín a zachytil v ňom sotva badatel'ný, no predsa stále prítomný dych vel'rieky" (Habaj 1980a, 187-189).

Postupne l'udia zdvihli hlavy a po mobilizácii išli bránit' svoju republiku. Aj v Lipovej Osade túžia po mieri, po chvil'ach pokoja, ved' teoreticky len kvôli tomu sa nalopotili a nadreli. Odmietajú tak prevrátený svet plný vzbury a vojny; konajú jednotlivo aj spoločne za myšlienku slobody a bratstva. Občas ich však hnetú myšlienky menejcennosti; zvit'azi však idea, aby po človeku zostala nezmazatel'ná stopa. Žial', demoralizujúci vplyv rozhodnutia vel'mocí je neúprosný a sužujúci. Kolonisti musia organizovat' odsun svojho zvyšného majetku do severnejších okresov. Autor pritom opisuje aj dobrosrdečných mad'arských pomocníkov, ktorých neskôr zbili len kvôli tomu, že boli nápomocní kolonistom pri ich stáahovaní majetku. Taký či onaký vývoj politickej situácie tak negatívne zasiahol dvadsat'ročnú prítomnost' kolonistov na Žitnom ostrove. Aj v jednotlivých myšlienkach a výpovediach sa konfrontuje dobová realita napätých rušných chvil': „,vás si poznačili, majú zmapované celé pohraničie, presne vedia, kto bol čím, ich tunajši l'udia isto nezahál'ali, usilovne zhromažd'ovali informácie o nebezpečných elementoch, ktorým bude treba najskôr vykrútit' krk. Pre republiku sme [...] hrdinami, ktorí za ňu prelievali krv, ale čo sme pre tamtých, ktorí sem onedlho pridu, čo sme my v ich očiach? Vojenskí zbehovia, zradcovia uhorskej vlasti, odpadlíci, čo pozdvihli zbraň proti monarchii i jeho cisárskemu veličenstvu“ (Habaj 1980a, 207-208).

Habaj spomína riešenie problému mad’arskej menšiny v Československu i územia, na ktorom žije. Je to doba, v ktorej: „Spev viazol v hrdle, jazyky v ústach meraveli, napokon sa každý pohrúžil do seba, len šuchot šúpolia zaznieval do ticha“ (Habaj 1980a, 212). Zaujímavým momentom je spomienka na rokovania medzi zástupcami československej delegácie a mad'arskej vlády o možnosti politického riešenia hraničných teritórii ( $v$ budove okresného úradu v Komárne; medzi delegáciami vedenými Jozefom Tisom a Kálmánom Kányom; od 9. do 13. októbra 1938; ako akási predzvest' Prvej viedenskej arbitráže). Na základe diktátu tretina slovenského územia zostala ,pod čiarou : autor uvádza konkrétne reálie pohraničného 
kraja, pričom jednotlivé postavy tento fakt vnímajú ako akýsi neskutočne zlý sen (jazdci na koňoch s mad'arskou zástavou, výkriky ako: Drotári von!, samovražda ako úniková cesta z reality a podobne). Aj samotní kolonisti sa pritom delili na čestných a kolaborantov. Jedni mlčky trpeli posmešky, nadávky a pl'uvance sfanatizovaného davu (pravda, so zatatými pästami), iní opreteky písali privítacie prejavy, stavali slávobrány, šili (aj ked' v obrátenom poradí farieb) mad'arské zástavy, zakálali svine, naplńali demižóny a slúžili sviatočné omše. Je to teda opis dobového virvaru, kde sa krivia l'udské charaktery a clonou hmly sa zahal'uje l'udská statočnost'. Tváre evakuantov so sedemdesiatkilovou batožinou sú obrazmi mučeníkov, pričom vojaci sú priam náboženskými fanatikmi, pomätencami, slaboduchými neborákmi. Čitatel'sky efektívny je pritom opis slovenského odporu s vidlami v rukách, ktorý však žandári, vykonávajúc dôkladné prehliadky po gazdovstvách, úspešne potlačia. Prichádzajú tak chvile obavy o holý život pri neustálom stupňovaní napätia (až tyranie) zo strany žandárov: „Obrátili dom hore nohami. Veci zo skrín a truhlíc vyhádzali na zem, odtiahli postele, rozpárali slamníky, periny, vysypali drobnosti zo zásuviek. Na povale $v$ hromade zbožia našli fotografiu prezidenta Masaryka $v$ zasklenenom rámčeku. Zniesli ju dolu ako velikánsku trofej, s krikom ju otŕčali domácim, smiali sa a kričali jeden cez druhého: - Čo je to, čo je to? Potom jeden z nich tresol obrázok o stenu, sklo sa vysypalo, rámček sa polámal, iba podobizeň zostala neporušená. Žandár ju prederavil opätkom čižmy, dupotal po fotografii dovtedy, kým ju neroztrhal na kúštičky a nezašliapal ich do blata“ (Habaj 1980a, 248-249). V zásade možno uviest', že obývané usadlosti kolonistov civilisti nechali zatial' na pokoji, ale uniformovaní nie. Tak postupne živá kolonistická Lipová Osada začala pôsobit' dojmom skoro mŕtvej dediny: gazdovské domy spustli, obývané domy onemeli. Hmotný majetok kolonistov prepadol v prospech Mad'arska. Nové mocenské orgány neustále vyzývali obyvatel'ov k disciplíne. Po Slovákoch-kolonistoch sa akoby prepadla zem; okolitá príroda mlčala. Prichádzali nové vozy i l'udia na gazdovstvá po kolonistoch; postupne tak obsádzali všetky prázdne usadlosti. Títo ,vitézi dostali nové príbytky ako odmenu z rôznych príčin a za rôzne zásluhy od mad'arského štátu. Po drastických žandároch však prišiel vládny komisár, ktorý nebil, ale len agitoval za dobrovol'ný odchod tých, ktorí aj napriek hrozbám mohli a chceli zostat'. Autor dôsledne opisuje ničenie všetkého, čo za dvadsat' rokov rástlo a zmáhalo sa po oboch stranách Lipovej Osady (vid' spomínané vysádzanie agátu). Plač, nariekanie, bedákanie pri odsune l'udí s majetkom poukazuje na bezmocnost' a vratkost' l'udského života, štastia, úspechu, spokojnosti, bohatstva, lásky i vernosti. Posledné zbohom dali kolonisti počas dlhej cesty Alžbetinmu Dvoru, Dunajskej Strede, Orechovej Potôni, Svätému Michalovi na Ostrove, Vel'kému Aboňu, Vel'kému Légu, Vel'kému Mederu, Úzoru... Obyvatel'ov Lipovej Osady tak evakuovali na Ponitrie. Ich privítanie na severe však ani zd'aleka nebolo privetivé (niet tam miesta pre nich, nakol'ko berú chlieb domácim l'ud'om); najsamprv ich majú za prítaž, vyhrážajú sa im. Autor však uvádza svoj demokratický postoj, že všetko si žiada čas, trpezlivost' a porozumenie. Na konci prvej časti trilógie sa teda vracia k idei, z ktorej vyviera aj začiatok jeho rozprávania. Ĺudia - najmä Slováci - sa musia zmierit' a dúfat' vo vytvorení porozumenia aj s Neslovákmi. Z toho dôvodu kolonisti po príchode na Ponitrie ,išli d'alej, bližšie a bližšie k l'ud'om s palicami, motykami i vidlami v rukách, 
akoby vrasteným do tej sivej, mrazom skutej zeme pod ich nohami. Aj vietor stíchol v očakávaní chvile, ked' sa l'udia stretnú zoči-voči“" (Habaj 1980a, 288).

V roku 1981 v erudovanom vydavatel'stve Slovenský spisovatel' vyšiel druhý zväzok trilógie - teda Kolonisti II. Z tejto časti sa národnostná problematika takmer úplne vytratila, nakol'ko „kolonisti sa vracajú skúsenejší, starší, poučenejší dejinami, zmenení, ale $v$ základe $v$ nich pretrváva čosi z onoho určujúceho kolonistického životného pocitu - životaschopnosti, činorodosti, odolnosti aj prispôsobivosti. Pretrváva, a predsa možno aj odchádza. Lebo nie každý vydrži horúci vzduch Lipovej Osady, nie každému je dožičené z vojny sa do nej vrátit' a nie každý sa rovnako l'ahko znovu včleňuje do novej skutočnosti“ (Chmel 1983, 133). Osadníci prichádzajú spät' zväčša bez úmyslu pomstit' krivdy, ktoré boli na nich spáchané. Autor pritom svoj zretel' orientuje opät' na postavy, lenže tentoraz nežijúce v harmonickom súlade s prostredím, ale vo virvare vojnového času. Text tak nie je kompozične vytvorený na základe preferovania časovej línie fabulačnej postupnosti; napriek tomu vyvoláva dojem epickej kompaktnosti. Preferujú sa v ňom udalosti pred psychologickými sondami.

V tejto časti sa kolonisti po návrate snažia uviest' usadlosti do pôvodného stavu - tomuto problému venuje autor v sujete najviac priestoru. Odvijajú sa pritom aj individuálne osudy jednotlivých postáv, ale všetko, čo sa s nimi deje, je znovu späté s kolektívnym úsilím opätovného (symbolického) zakorenenia sa do pôdy, odkial' ich nepriaznivé pomery vyhnali. Navonok sa l'udia ešte zmáhajú, no zvnútra už život upadá. Dôležitú úlohu popri tom hrá aj topografia kraja, ktorá netvorí len nevyhnutný rámec či pozadie, ale je aj činitel', ktorý formuluje samotné charaktery. Vytvára sa tak román dôležitý i pôsobivý, výpovedný o dnešku a nás samých. $V$ ňom sa v podstate nič nemení, len všetko pokračuje. Badatel'ný je však generačný posun: zjavnejšími aktérmi života (aj dejov) sa po otcoch stávajú synovia a ich problémy $s$ novou realitou povojnového obdobia. Sú to oni, ktorí musia pokročit' o celú epochu vpred - v tom je aj ústredné dramatické jadro tohto textu. Obraz aktuálnych historicko-spoločenských pomerov tak nie je dramatický, konfliktný; nový život je vcelku konsolidovaný a úspešný, usporiadaný; do popredia vystupujú skôr osobné, individuálne a rodinné problémy či vzt'ahy. Prekážky návratu a tým nového konfrontovania so zmeneným prostredím sa Habajovi darí vystihnút skôr ako detailnú starostlivost' o jednotlivé línie hospodárenia, než ako obraz nekonečných starostí. V texte však pritom evidujeme „určitú nedôraznost', rozvláčnost', detailizovanie..." (Truhlář 1982b, 5). Na druhej strane - až paradoxne - vzniká dojem pokojného toku v pozadí skôr naznačujúceho rozprávania. Postupne sa vynárajú názorové a sociálne spory, vrcholiace novým spoločenským usporiadaním, a teda aj aktuálnym riešením národnostných problémov v pozadí trpenej existencie.

Románový čas druhej časti (ako sme už spomínali: obdobie od konca vojny približne do polovice roku 1947) má svoju logiku v živote postáv i v dejinnom procese. Autorský dôraz sa kladie menej na nacionálne a viac na sociálne, politické. Kolonisti si tak v danom chronotope nanovo musia riešit' problém svojej l'udskej dôstojnosti a spoločenského zaradenia. Habaj tým naplnil text zmysluplným dejom, konaním, prácou, ideami a historickým priestorom, v ktorom kolonisti žili a ktorý chcel nielen opísat', ale predovšetkým vysvetlit'. V tejto časti ,,je otázka umeleckej štruktúry cel- 
kom iná. Línia národnostných treníc okrem určitých náznakov úplne mizne“ (Truhlář 1982a, 21; slová Daniela Okáliho). Sila diela ,je naozaj v mikrokresbe [...] a v perfektnom vystihnutí atmosféry“ (Truhlář 1982a, 21; slová Júliusa Nogeho). Prvá čast' ju má ucelenú, kde je viac priestoru pre konflikty a širšie uchopenie celého problému. $V$ druhej časti táto celistvá atmosféra chýba: pripravuje sa tak pôda pre nový kolektivizačný konflikt a ani nenachádza sa v nej celá rozloha historického vedomia. Habajovi sa pritom „Vynikajúco podarili jednotlivé scény, ale ústredná myšlienka sa kdesi vytratila“ (Truhláŕ 1982a, 22; slová Karola Rosenbauma). V druhej časti románu sa dynamika epických dejov stupňuje v pozadí neobyčajnej zmyslovej konkrétnosti podania. Stále pritom dominuje realistické rozprávanie, pričom vel'ký dôraz sa kladie na dialóg - strieda sa klasický a kolektívny dialóg, vnútorný monológ a na minimum obmedzený autorský komentár, prísne spätý s epickým dianím. Autora ako epika zaujima l'udský čin, prax, aktuálne rozhodovanie. Preto má román strhujúci rytmus v pozadí túžby premenit' provizórium na istotu - a to predovšetkým každodennou l'udskou prácou.

Kolonisti ako predstavitelia minulosti či predvojnových istejších čias museli v pozadí historických premien podstúpit' nemalé krivdy. Viacerí spokorneli a stali sa ohl'aduplnejšími, iní sa zmenili na nepoznanie. Autor túto situáciu vyjadruje ich vzájomnou interakciou a uvedomením si nel'ahkého rozpoloženia, ved': „osudy celých národov visia často iba na vlásku. Neraz stači málo, celkom máličko, závan vetríka, náznak činu, slovo-dve, a pohne sa lavína, ktorá zmetie všetko pred sebou“ (Habaj 1981a, 42). Takúto (i ked' menšiu, psychickú) ,lavínu museli podstúpit́ kolonisti pri príchode do severnejšie položených Ulmárov, ked' ich nevítali sol'ou a chlebom, ale kosami a vidlami. Čas sa teda obrátil, avšak sny o južnom Slovensku pretrvávali aj vo vnútri jednoduchého človeka, bývalého obyvatel'a Žitného ostrova: „na svete je iba jediný kraj, o ktorom sa jej sníva. Je to ten, v ktorom prežila detstvo, kraj melónov, dýň, kukurice, pšenice, papriky, marhúl' a tabaku, jej Žitný ostrov, prežiarený slnkom, ktorý i v tejto chvíli akoby chcel učinit' zadost' slovám svojej ctitel'ky a presvedčit' neveriacich“ (Habaj 1981a, 28). Správa o tom, že agátový les noví obyvatelia na Dolniakoch vyrúbali, neprináša pokoj do duše novým obyvatel'om Ponitria. Dôležitý je u nich pocit domova, ktorý je lokalizovaný už na južnom Slovensku (my sme doma tam, pri Dunaji, v kraji s artézskou studňou so živou vodou). Aj v tomto prostredí - v retrospektívnom podaní autora - spomínajú na vlastný prerod, ked'zo správcov a nájomcov sa postupne stali vlastníci obydlí v nových majeroch. Prežili aj vojnové útrapy a skazy: Habaj (pars pro toto) spomína Nemcov, ktorí pri Komárne vyhodili mosty cez Váh do vzduchu. V spomienkach i činoch sa prízvukuje pravidelný kontakt evakuantov v novom chronotope, ich nezištnost' a negácia nevraživosti, závisti či pokrytectva. Takto sa pre vnímavých čitatel'ov spoločenstvo ponižovaných a zrádzaných, obetovaných mocnými v záujme princípu menšieho zla, vykryštalizuje. Aj v tomto prostredí kolonisti tahajú káru svojich starostí, avšak autor citlivo opisuje odlišnost' ich každodenného života v pozadí binárnych opozícií sever - juh, resp. domov - cudzina. Atribút zeme, ktorý je mimoriadne dôležitý, do určitej miery vtedy a tam stráca čaro a prítažlivost'. Neubudne však z nádeje, ktorá je determinovaná nielen odchodom zmobilizovaných mužov do Slovenského národného povstania, ale aj príchodom nového pokolenia, ved': „Zem už očakáva človiečika, len 
aby rýchlo vyrástol a zmocnel, aby si mohol zastat' na prázdne miesto po miliónoch padlých a ubitých" (Habaj 1981a, 67).

Emocionálne a empaticky je opísaná možnost’ návratu kolonistov na južné Slovensko po druhej svetovej vojne. Ženy so štipkou nedôvery však musia íst' spolu so svojimi razantnými mužmi. Viera v lepšiu budúcnost' sa tak postupne skíbi s túžbou o lepši život. Opis opravy domov či stavania plotov v Lipovej Osade prinavráti slovenský život vo svojej všeobecnosti i zvláštnosti; výmenný obchod s cukrom podopiera prirodzený l'udský charakter. Príchod kolonistov do osady je sprevádzaný akoby krásami prírody (belasá obloha, horúce slnko, mierumilovný spev škovránkov). Z Bratislavy sa ich cesty rozchádzali rôznymi smermi, najmä domov, na Dolniaky. Opät' priniesli so sebou slovenčinu ako živý jazyk, ktorú chcú rozsievat' aj pre tých, ktorí jej rozumejú, ale rozprávat' sa hanbia. Autor pritom opisuje aj ambivalentnost' reálnych i bezhlavo sa hlásiacich ,hrdinov so zásluhami. Informácia o novej pozemkovej reforme $v$ ich očiach determinuje aj plamienky roztopaše, ktorá často môže pripravit' márnotratných l'udí o rozum či mužskú dôstojnost'. Autor tematicky a motivicky dáva pozor, aby sa hrdinovia nedostali z blata do kaluže, aby svoju l'udskú čest' nestratili ako peniaze hodnotu počas vojnových rokov (zlaté časy predvojnové...). Spomienky na obdobie vyhnanstva potvrdzujú fakt, že život je nesmierne dôležitý (aj napriek dobovej politike). Kolonisti si v Lipovej Osade či v Olšanoch presne pamätajú na časy odlúčenia, ked' dvadsiati museli spávat' vo vlhkej šalande či umývat' sa vo válove pri studni. Opisuje sa pritom aj súčasný stav ,novej dediny a všadeprítomné vojsko pre zabezpečenie poriadku. Ĺudia-Slováci nádej prikladajú novovzniknutým československým úradom, pričom ich komplexnú činnost' Habaj opisuje nasledovne: „Olšiansky predstavitel' štátnej moci požiadavke poškodencov vyšiel maximálne v ústrety. Bez dlhých reči spísal záznamy o škode, o tom, kto ju spôsobil, i o spôsobe jej náhrady. Súčasne sa s chlapmi dohodol o výkone úradného rozhodnutia. Malo sa vykonat' v nasledujúci deň a kvôli jeho hladkému priebehu mali z Olšian do Striebornej pricestovat' aj dvaja muži v uniformách" (Habaj 1981a, 124). V pozadí dobovej politiky a Košického vládneho programu sa hl'adali nepriatelia štátu. Jednotlivé výpovede a repliky l'udí odzrkadl'ujú povojnové časy a akúsi silu: „zem po tých Mad'aroch, čo najviac kikirikali proti republike, musia dostat' naši l'udia [...] Rozbijal si republiku? Rozbijal, to nepoprieš, chod' si teraz do frasa, za tými, ktorých si velebil..." (Habaj 1981a, 125). Autor pritom opisuje nekonečne dlhé mesiace, ked' tabak či klobása mali väčšiu hodnotu ako peniaze. Zo všeobecného hladu sa vyskytujú rany na tele i duši. Habaj to (pars pro toto) vyjadril z aspektu drobného jednoduchého človeka-kolonistu nasledovne: „tridsiaty ôsmy rok ta poznačil, poznačil t́a, ako nikoho z celej rodiny nepoznačil, ale i tak, či sa ti treba do nekonečna umárat' a trápit', dost' si si vytrpel po špitáloch, kým t'a doktori aspoň trocha pozliepali dohromady, teraz už začni žit', prekristapána žit', máš už tridsat'dva rokov, spamätaj sa, zasmej sa na svet, vyjasni si tvár!" (Habaj 1981a, 134). Je preto aj z autorského hl'adiska mimoriadne dôležité, aby nastal všeobecný pokoj, teda to, aby na moste $v$ Komárne nestáli financi. Je preto žiaduce aj na druhej strane sa poučit' a netúžit' po návrate starých čias (napríklad predtrianonských hraníc). Je potrebné pochopit', že aj susedia sú len l'ud'mi a priznat' si pritom vlastné staré politické a historické chyby... 
Návrat kolonistov je však celkovo charakterizovaný vitálnostou; niektorí starší, skúsenejši l'udia však majú ambivalentné pocity o návrate na ,kukuričný ostrov'. Nová doba pritom prináša nové možnosti práce, pričom po sedemročnej okupácii mosty na dolnej časti Váhu ležali v troskách a vlaky premávali až hrôzostrašne. Symbolom fyzického i duševného spustnutia kraja je cintorín, ktorého stav sa po návrate kolonistov do Lipovej Osady opisuje až tragicky: „Sedem rokov pustli hroby kolonistov. Chumáče suchých tráv, žihl'ava, agáčie, poplazy ostružín, tŕne divých ruží zaplienili priestor cintorínov, l'ahko postupovali od plotov k vel'kému križu s ukrižovaným Kristom, l'ahučko, l'udská ruka nepribrzdila ich nenásytnost"“ (Habaj 1981a, 149). Je teda prirodzené, že v tomto chronotope poškodenec má (ba čo viac: chce mat') nárok na odškodnenie. $Z$ dnešného aspektu sa dá chápat', ak sa týmto kolonistom „,všemožne vychádza v ústrety, dostanú sa k živnosti, k štátnej službe, ujde sa im rolí i statku, len treba vstat' a ist', ústa otvorit', svoje si povedat', zažiadat', naliehat', nedat' sa odbit' neurčitou odpoved'ou, íst' si za svojou vecou ciel'avedome..." (Habaj 1981a, 163). Bola to teda doba, v ktorej niektorí občania štátu nadobúdali domy, vily, záhrady či vinohrady občas až za smiešne ceny. Boli to roky, ked' sa poškodenec musel tlačit' dopredu, nezdráhat' sa a nestát' bokom. Autor pritom celkovo opisuje postupné pozviechanie sa Lipovej Osady z frontovej biedy. Je to symbol znovuzrodenia a odhodlania za nové - azda krajšie - zajtrajšky. V texte sa objavujú aj korienky komunistickej bunky v centre $s$ Jonášom Hruškom (čítanie ,červených novín potajomky v osade, uvedomenie si dôvodov mozol'natých rúk jednoduchých pracujúcich a podobne). Dôležité je však splynút' s ostatnými, použit' pritom mäkkú spisovnú reč pôvodných kolonistov, opät' dbat' na dobré susedské vztahy, o dobrú povest' a vyhýbat' sa škriepkam a tahaniciam.

Vitłazné povojnové vol'by prinášajú do Lipovej Osady nové obdobie. Prichádza však aj čas žatvy a mlatby - teda zohýbanie chrbtov a odieranie kolien. Doba a skúsenosti priam determinujú už duchovnejšiu vyspelost' kolonistov, ktorí si uvedomujú svoje reálne možnosti a postavenia: „Tentoraz ani my nezastaneme v polceste, neboj sa, teraz to nebude, ako bolo po prvej svetovej, aj my sme zmúdreli, naši l'udia tamhore tiež nespia, čas dozrieva, veru hej!“ (Habaj 1981a, 209). Nasledujúce obdobie je determinované elektrifikáciou dedín a osád. Aj z národopisného hl'adiska je zaujímavý relatívne detailný opis prvej povojnovej tradičnej svadby v Lipovej Osade. Zavedenie nových poriadkov, odpozorovaných v Moskve, však pomáha modernizácii osady a všeobecnému pozdvihnutiu životnej úrovne kolonistov. Zaujimavá je pritom ich debata o dobovej dohode o presídlení obyvatel'stva medzi Československom a Mad'arskom. Uvádza sa úsilie republiky o národný štát, o zbavenie sa silného mad'arizačného vplyvu. Lipová Osada sa tak stáva dynamickým článkom, symbolizujúcim dobovú atmosféru v celej republike. Informácie sa dostávajú ku kolonistom už nielen rádiom, ale aj vd'aka elektrine či telefónu. Tak sa vlastne obdobie okupácie, naplnené rozmanitými príkoriami, núdzou, ponižovaním či stratami, stáva zlým snom, ktoré na úsvite dňa, prirodzene, zmizne v nekonečných hmlách noci. Hmatatel'ným dôkazom nového zriadenia je osvedčenie o národnej spol'ahlivosti, vd'aka ktorej všetci lojálni občania zostávajú ,na jednej lodi . Autor emotívne opisuje rôzne spôsoby získavania tohto papiera, pričom poukazuje aj na dobrých i zlých Mad'arov, Nemcov, Slovákov. Aj v pozadí tohto stavu je zrejmé, že nemožno 
súdit' kolektívne, lež individuálne. Je však dobovo príznačné, že niektoré repliky kolonistov vychádzajú z vlastného prežitia bývalého neúprosného stavu aj vo vztahu k druhému (bývalému) občanovi: „teraz sme ti dobrí, všetkým sme vám dobrí, anjela vášho, dnes sa vám už nechce mondokovat', zrazu úpenlivo hl'adáte v pamäti opl'uvané slovenské slová, lámete si jazyk, presviedčate o svojom slovenskom či aspoň slovanskom pôvode, hl'adáte vhodného predka až do siedmeho kolena, teraz, ked' slovanský svet vychádza na výsInie, cnie sa vám zrazu po drotárskom dedovi, dali by ste neviem čo za to, keby ešte visela jeho krošňa v komore..." (Habaj 1981a, 264). Až komicky znie fakt, že niektorí ani ceknút' nevedia po slovensky, hrnú sa do úradov a uchádzajú sa o občianstvo. Nechce sa im za hranice, a tak spievajú celkom opačne ako by im kázalo vnútorné presvedčenie. Na druhej strane je však z pohl'adu dobovej atmosféry celkom prirodzené, že l'udia hl'adajú onen tenký krajček istoty, ktorou je aj v tejto novej dobe práve zem. Je však dôležité uvedomit si, že táto záruka je prchká a menlivá. Aj v Lipovej Osade je realita iná: objavujú sa šmelinári na čiernom trhu ako dôsledok absencie tovaru. Celkovou kontamináciou dobra a zla však kolonistom nezostáva nič iné, len začat' odznova, verit' kontinuite, ktorá v symbióze $s$ prírodou prináša, ba musí prinášat' svoje fyzické i duchovné istoty: „sady a dvory spriesvitneli, vidno do nich hlboko. Na záhumniach zoschnuté kôpky zemiakovej vňate signalizujú príchod jesene. Dozrieva kukurica, vo vánku, čo ohýba kukuričie, čosi sipí, šuští [...] Aj to je jeden z priznakov končiaceho sa leta" (Habaj 1981a, 308). Po jeseni a zime však príde jar a leto, ktoré kolonistom prináša všakovakú úrodu, pokoj, porozumenie - teda náležitý dôstojný a l'udský život na južnom Slovensku.

V roku 1986 v prestižnom vydavatel'stve Slovenský spisovatel' vyšiel tretí zväzok trilógie - teda Kolonisti III. Habajova rozprávačská metóda je v ňom (podobne) postavená na lineárnych pribehoch a verne zachytávanom detaily. Stretávame sa tak so známymi rodmi a rodinami, lenže autor venuje pozornost́ skôr zanikajúcim než pokračujúcim generáciám. Každá kapitola hovorí o individuálnej postave a jednom rodinnom prostrediu; všetko časovo a priestorovo presne lokalizované. Prevládajú silné rodové putá, ktorými sa manifestuje spätost'. Vel'ká dunajská povodeň z roku 1965 sa stala pre Habaja príležitost'ou, aby sugestívne a umelecky účinne predviedol svoje umenie hlbokej psychologickej charakteristiky postáv. Jeho človek sa opät' bezbranne ocitá zoči-voči ničivej nevypočitatel'nej sile, ktorá zasahuje do jeho osudu. Znovu začína boj o vlastné (ne)bytie. Habaj je pritom opät' dobrý pozorovatel', má zmysel aj pre poéziu krajiny. Vytvoril tak „,dielo čítavé a zaujímavé, hoci skôr románové svedectvo ako románovú metaforu“ (Bžoch 1987, 4).

Rámcom tretej časti je povodeň v Lipovej Osade, ktorá je zničená, avšak vláda postaví novú. Tak sa posledné zvyšky slovensko-mad'arského antagonizmu odplavia a vzniká pocit súdržnosti. Ústrednou myšlienkou tejto časti je, že Slovensko pod vedením pokrokových sil zbavilo južné Slovensko všetkých národnostných či rasových problémov. Aj vd'aka tejto kružnici Habaj vidí slovenské historické udalosti ako dejiny kontinuálneho pozitívneho vývinu. Je to príbeh ohrozenia a následnej záchrany, solidarity, vzájomnej pomoci, spolupráce pri obnove hodnôt, v ktorých sa premieta jadro celého diela a tým aj jeho ideové posolstvo. Presvedčivo symbolizuje charakteristické zmeny, ktoré sa stali v novom politickom usporiadaní 
a ktoré dali l'udsky koexistenčnú podobu životu v tejto časti krajiny. Po prekonaní nebezpečia, ked' sa celá krajina ponáhl'a s nezištnou pomocou, všetci pochopia, že patria spolu, že sú na seba odkázaní, že Slováci, Česi a Mad'ari za seba navzájom zodpovedajú. Takto aj Habajovu finálnu čast' trilógie ovláda duch porozumenia a spolupráce. Ak Rudolf Chmel charakterizoval prvé dve časti Kolonistov ako expozíciu a rozvinutie, tretiu čast' možno pokladat' za akýsi epilóg, ktorý dopovedúva, završuje, sumarizuje, bilancuje. Habaj pritom urobil krok vpred aj v tom, že „obraz minulosti nezredukoval na zovšeobecnený chod dejín, že rozvinul aj podoby bezprostrednej a reflektujúcej, individuálne transponovanej skúsenosti, ktorá dáva jeho rozprávaniu presvedčivost' a silu. Kolonistami ako celkom sa úspešne zaradil do kontextu úsilí našej románovej prózy zameranej na nový výklad koreňov súčasnosti a budúcnosti domova" (Šabík 1986, 5). Vo svojom texte smeruje skôr $\mathrm{k}$ vyrovnaniu a urovnaniu ako $\mathrm{k}$ samotnému riešeniu. Je to jednota celku $v$ jeho stavebnej harmónii v pozadí nevel'kej dynamickosti. V Kolonistoch III „,vo vztáahoch k l'udí aj v psychológii jednotlivcov sa ešte pripomínajú rôzne ,zádrhele z minulosti, kriticky sa spomínajú aj všelijaké nové javy a problémy z politicko-spoločenského života, ale to všetko je iba na okraji románovej problematiky. Jej jadro a zmysel by sme mohli nazvat' zmierenie, vyrovnanie, až harmónia“ (Noge 1987, 77). Kolonisti III na rozdiel od Kolonistov I sú viac románom jednotlivcov či rodín - ako kolektívu. Jej záver je aj napriek živelnej pohrome potvrdením nachádzania nového domova pre jednotlivca. Od udalostí a činov sa tak autor pri zvýrazňovaní princípu vnútorných monológov viac priklonil k psychologickým sondám. Aj napriek tomu v tretej časti umelecky, dejove a osudovo vrcholia udalosti: vo svete roztrúsené postavy sa opät' schádzajú v hniezde; sú zmierlivé a l'udské. Povodeň „stmelí l'udský kolektív v zápase so živlom, prebudí l'udskú spolupatričnost', vzájomnú pomoc, súcit a úctu“ (Bartko 1986, 6). Kolonisti nezúfajú, aj ked' sa im všetko rozpadá a hynie pred očami. Zo severu si priniesli akýsi štít sebazáchovy, nadobudnutý za stáročia v zápase so skúpou, kamenistou pôdou.

Tretia čast' sa v prvej polovici venuje obrazu postupného zakotvovania rodín, je odrazom rozvíjania života v úrodnom kraji či prehlbovaním vztahov niekol'kých rodín. Je konkretizáciou zmenených čias a autorovho úsilia, aby ukázal, ako sa pôvodné perspektívy a ciele niektorých l'udí (z)menili. Je to Habajovo autentické videnie toho, čo vedela urobit' stáročná voda; čo všetko bolo treba, aby l'udia, postihnutí touto ničivou katastrofou, zachránili aspoň ono najdôležitejšie: holý život a svoju l'udskú čest'. V tejto časti diela sa čitatel' posúva do doby šest'desiatych rokov 20. storočia, do obdobia relatívneho blahobytu. Tento fakt podopiera aj osobné auto ako symbol bohatstva l'udí v Lipovej Osade či Olšanoch. Poukaz na kúpu Škody Octávie svedči o postupnom stieraní sociálnych nezrovnalostí danej spoločnosti. Auto „symbolizuje aj všetky zmeny, tie hlboké premeny tohto sveta, ktoré tu za krátkych dvanást'-pätnást' rokov, naozaj iba za taký krátky čas, poriadne poprevracali hodnoty, čo sa na tomto svete ustálili za predchádzajúce nekonečne dlhé obdobie a drobnému robotnému človeku priznali pod slnkom spravodlivejšie miesto [...] Áno, škodovka, o ktorej je reč, nie je iba obyčajnou užitočnou vecou [...] je i potvrdením ich l'udskej dôstojnosti, nového miesta na svete" (Habaj 1986, 14-15). Alúzia spomienok na nádennícky život, odtŕhanie od úst či neustálu poctivú drinu 
na cudzom je čitatel'sky efektívna, prinášajúca však aj určitú pachut' starých rán. Opis chronotopu po združstevňovani dediny prináša svoje klady i nedostatky. Autor však zdôrazňuje axiómu, že chudobný človek si vie ocenit' aj kúsok štastia. Doba vychádza z obdobia nadšených kortešačiek s ampliónom pre družstevnú myšlienku. (Ako určitú zaujímavost' uved'me, že po vojne v gutianskom chotári, v Dedine Mládeže, pestovali ryžu - pozn. P. Š.) Republika sa postupne buduje, rozvoj je hmatatel'ný. Niektoré postavy však v binárnej opozícii podozrievavo skúmajú každú novotu. Habaj týmto autorským postupom akosi kompenzuje prehnaný idealizmus a huráoptimizmus. Prízvukuje objektívnu realitu spolužitia Slovákov a Mad'arov na Žitnom ostrove, pri ktorej však kriticky uvádza motív t’ažšej dochádzky do slovenskej školy v Olšanoch (než do mad'arskej v Lúkach). Vynára sa v týchto končinách z úst kolonistov dodnes platná otázka, že „,prečo reč vzdialenejších českých krajov plynie z úst týchto chlapcov či dievčat omnoho l'ahšie, bezprostrednejšie, štavnatejšie a plynulejšie, než by z nich za ten istý čas tiekla slovenčina?" (Habaj 1986, 39). Slovenčina sa aj v tomto období často chápe iba za akési nezrozumitel'né nárečie sluhov, bírešov či rôznorodej bedače. Nové časy však majú priniest' (a aj prinášajú) l'udskejšiu a privetivejšiu tvár doby, ktorá rozmetá staré, nespravodlivé a nastolí vládu dôstojnosti. Táto myšlienka ide ruka v ruke so spoločným hospodárením a výstavbou prvých komunálnych objektov v Lipovej Osade. Budova nového hostinca a obchodu so zmiešaným tovarom je symbolom akéhosi znovuzrodenia. Autor sa pritom dotýka aj chronologických historických udalostí: revolučnej oddanosti povojnového zriadenia, myšlienky maloburžoázie a kulactva či vytvárania nových okresov. Opisuje rôznorodú spoločnost', ktorá sa zíde na pracovisku (bývalý aktívny nyilas, skrachovaný advokát, nespol'ahlivý dôstojník armády, nedávny príslušník bezpečnosti-opilec). Kritizuje však aj existenciu nedostatkových tovarov, zháňanie ktorých prináša so sebou špekulácie a podplácania. Na príklade otca a dcéry typizuje nedôveru k cudziemu prostrediu (doma je bezpečné, mimo domova vd'aka vnadidlám nebezpečné). Opät' sa zdôrazňuje vztáah l'udí k družstvu, pričom sa vytvára aký-taký reálny život družstevníkov v pozadí dobovej politiky a reálii: „Zeme majú málo, len tol'ko, čo aj iní dedinčania, ale tí koňa nechovajú a navyše dostanú z družstva aj naturálie, pekný prídel zrna, pšenice, jačmeňa, kukurice, okrem toho všeličo z družstevného uchmatnú a navláčia si do dvora, im je hej!“ (Habaj 1986, 71-72). Komicky znie fakt o absencii d'ateliny, ktorá zmizla z hektárového pol'a za hrádzou. Postoj revíznej komisie družstva je však ambivalentne príznačný dobe. Okolie sa pritom opisuje aj s určitou nostalgiou a konštatovaním zlého stavu: samoty sú opustené a polorozpadnuté, často s prevalenou trstinovou strechou, sady sú neprehl'adné vd'aka rozmanitému tŕniu. $V$ tomto desatročí postupne zmiznú aj posledné pamiatky klasického kolonistického života. Na druhej strane štátna politika prináša aj istoty (ako napríklad nový mzdový poriadok, ktorý zaručuje ženám rovnakú odmenu podla ich výkonu ako mužom), pričom ako Damoklov meč visí nad hlavami kolonistov otázka zachovania si materinského jazyka. Pri postupnom rozširení zmiešaných manželstiev sa stávalo až pravidlom, že synovia a dcéry „obdivuhodne rýchlo zapadli do nového prostredia, čoskoro mleli, čo aj nedokonale, len po mad'arsky, za rodný jazyk akoby sa hanbili, vari si mysleli, že tým stúpnu u svojich nových pribuzných na cene“ (Habaj 1986, 79). Pohl'ad kolonistov sa roz- 
del'uje najmä vekovo: starí hl'adia dozadu a tak plejú zelinu z hrobov a zapal'ujú sviečky, mladí očakávajú modernizáciu okolia a pozerajú sa dopredu k svetlejším zajtrajškom. Mnohí tak odchádzajú do miest, fabrík, škôl a úradov - väčšina z nich sa zamestná v komárňanských lodeniciach. $\mathrm{V}$ pozadí toho autor poukazuje aj na jednoduchého typizovaného človeka, ktorý si chráni svoje tradície, ale pochvalne sa vyjadruje aj k danostiam, ktoré mu priniesol socializmus. Pričom: „vyvoláva si v pamäti, oživenej akýmsi zázrakom, nevysychajúcej, dávne zážitky, a vynárajú sa jej i drobné, nepatrné maličkosti, hotové skvosty medzi spomienkami, detaily, ktoré bývajú zvyčajne najpresvedčivejšie a svojou živou farebnost'ou naladia troška na tú správnu nôtu..." (Habaj 1986, 114). Vnútorne sa však kolonisti predsa len stotožňujú s južným koloritom, zostávajú ,ostrovanmi , pričom neustále si prisvojujú ono neopakovatel'né čaro prírody Žitného ostrova: „,nad Žitným ostrovom zhasína vel'ké červené slnko a odraz jeho žiary na západnom obzore farbí pozadie [...] A vánok, čo cez deň drieme kdesi v pririečnych úžl'abinách, sa teraz zobúdza a privieva sem riečnu vôňu. V ovzduší krúžia roje drobných mušiek, zrazu počut' zvuky doliehajúce sem zd'aleka, všetko je také, ako bolo kedysi, všetko má svoje miesto, zmysel, ustálený poriadok. Kolobeh života pokračuje i bez tých, ktorí odtial'to odišli..." (Habaj 1986, 115-116). Večný i dočasný odchod kolonisti - aj vd'aka svojej životnej empírii - vedia zdôraznit', ved' vzdialenejšie kraje chápu ako určité centrá vzdelanosti. Ich deti však musia zobrat' si so sebou aj do mesta znášanlivost' s rodnými, potrebu lásky a úcty, nevyhnutnost' odpúštat' slabosti, znášanie krivd. Autor pritom komplexne poukazuje na premenu človeka - zatrpknutý Lajoš Konrád stráca pocit neplnoprávneho a diskriminovaného občana republiky. Takýmto spôsobom sa postupné národnostné trenice strácajú do jesenných hmiel južných chotárov. Zostávajú teda najmä starí, ktorí, prirodzene, odmietajú trvalý odchod do mestského činžiaku, ba nepôjdu ani na sever k rodine či známym, nakol'ko doslovne túžia umriet' v Lipovej Osade. Napriek všetkému ich životný pocit nie je tragický, ale reálny a vnútorne pevný.

Občas sa do života kolonistov zapletie aj politika (alúzia na dobu s buržoáznymi nacionalistami, obdobie vykonštruovaných procesov, vylúčenie zo strany, vyhadzov z práce a podobne). $V$ tomto kraji je však už evidentné zhmotnené úsilie ich generácie, ktorá sa nebála prekážok či roboty. Spomína sa Slovenské národné povstanie a hrdinský boj odboja z aspektu pozostalých po padlých. Oni však túžia po porozumení. Uvedomujú si, že vtedy kadečo vyzeralo inak, aj človek sa mení, svet sa stáva spravodlivejším, lepšim, usporiadanejšim. Symbol murovaného plotu na dvore dvoch bratov a jeho zbúranie symbolizuje nové obdobie vztahov jednotlivca a spoločnosti v duchu očakávaní radostných chvil'.

Posledná čast' trilógie sa však završuje monumentálnym a umelecky silným obrazom vel'kej dunajskej povodne z roku 1965. Ono smrtel'né nebezpečenstvo tohto neskrotného živlu l'udí zjednotilo pri obnove života v zatopených oblastiach, na ktorej sa obetavo a pohotovo zúčastnila celá republika. Presvedčila všetkých, že solidarita l'udí nie je iba prázdnou frázou. Dunaj sa postupne nadúva, zaplavuje územia, šumí, pení sa, až útočí. Neakceptovatel'ná hladina spodných vôd skúša odolnost' nielen domov, ale aj l'udí či okolitej prírody, pre ktorú sú charakteristické „zabahnené polia s hnijúcimi, odumretými plodinami, celé lány povál'aného, očer- 
netého obilia, polia s nánosmi piesku, štrku a všakového rastlinstva, vymleté, ba aj celkom odplavené úseky ciest, popadané domy, žlté zvädnuté stromy v záhradách, spustošený kraj, nasiaknutý, páchnuci riečnymi pachmi, azda aj rybacinou..." (Habaj 1986, 289). Nekonečné dažde a množstvo vôd z hôr napomáhajú besneniu rieky. Autor pritom opisuje nel'ahký život strážcu hrádze, v osobe ktorého sa konkretizuje súdržnost' a kolegialita. Nepretržitá služba a vyhlásený druhý stupeň povodňovej aktivity deklaruje potrebu prítomnosti vojska, ktoré sype štrk a hlinu medzi hrádzu a ohradu. Presiaknutia a následné pretrhnutia hrádze prinášajú nielen skazu, ale aj vzájomnú nezištnú pomoc. Na jednej strane sa rúcajú výsledky l'udskej práce, obracajú sa navnivoč, na strane druhej aj napriek značnému rozruchu sa celkovo zhmotňuje spomínaná l'udská spolupatričnost'. Záchranári a civilisti sa pritom l'udsky zbližujú - a to nezávisle od národnosti. Autor až dokumentaristicky uvádza niektoré atribúty danej doby: helikoptéry nad zaplavenými územiami, filmári, evakuácia obyvatel'ov zaplavených oblastí, vojenské nákladné autá, koordinovaná práca evakuačných komisii a podobne. Nebezpečnému živlu však odolávajú najmä samoty, ktoré stoja na vyvýšeninách. Sú to ony, ktoré sa pamätajú na ničivú dunajskú povodeň z roku 1899, ked’ voda pretrhla riečnu hrádzu pri Léli. Individuálna i kolektívna pamät' je preto dôležitá aj v takýchto situáciách. Autor prívetivo opisuje obrnené obojživelné vozidlá a pomoc sovietskej armády. Na druhej strane je to aj obdobie uhynutých zvierat, karbolového zápachu a vel'kých l'udských trápení. Je však dôležité, aby človek nezostal l'ahostajný k veciam, aby sa zúčastnil na likvidácii škôd, pričom si musí uvedomit' aj neodbytnost' strácania sa kúskov minulosti. Čitatel'sky efektívne sa opisuje reálne i metaforické umieranie domov, ktoré klaknú na kolená, nachýlia sa, zakymácajú a klesnú až po zem. Aj v tomto rozpoložení však človek postupne zvit́azí nad vodou, premiestňuje sa (aj ked's t'ažkostami) z jedného bodu do druhého. Kritizuje sa pritom nečistý úmysel l'udských hyen, ktoré využijúc túto pohromu, vykrádajú opustené l'udské pribytky. Na druhej strane však vnímavý čitatel' musí pochopit' aj náreky l'udí zo zaplavených oblastí, kde sa všetko rozmočí, zniči v pozadí možných epidémií. Strácajú sa tak roztrúsené usadlosti a malebné samoty s dlhými verandami. Dočasný pocit zmaru a beznádeje sa však konkretizuje aj v aktuálnych rozpomienkach kolonistov: „Ako v tridsiatom ôsmom. Zase sme žobráci! Vtedy nás priviedli na žobrácku palicu tí smradi od politiky, a teraz zasa toto.“ (Habaj 1986, 277). Ĺudia si pritom postupne premietajú „,hodiny, dni a roky, počas ktorých na tie užitočné veci, čo ležia poničené tamto v bahne, v rozvalinách [...] zohýnali chrbát, zbierali mozole, predstavil si svoje drsné, sychravé rána, ktoré sa začínali tretou, ešte vlastne nočnou hodinou, tisícky navlas rovnakých rán, studených, tmavých, neúprosne jednotvárnych, krutých rán, v ktorých mu nebolo dopriate, aby si v teplej posteli povystieral kosti..." (Habaj 1986, 276). Na druhej strane sa po ústupe povodne začína horúčkovitá práca majstrov a stavbárskych remeselníkov čím skôr dat' l'udské obydlia do poriadku. Autor opisuje nastávajúce obdobie plných rúk roboty - súvisiace s obnovou pribytkov. K Dunaju prišli pomôct' zo všetkých končín republiky. Ako každá postihnutá obec, aj Lipová Osada dostala svoj patronátny okres, ktorý prijal čestnú úlohu niest' hlavné bremeno jej obnovy: materiálom, dopravnými prostriedkami, odborníkmi. Na základe toho sa vyslovuje vd'ačnost' „'lud'om tejto republiky, ktorá si svojich pri Dunaji nenechala zvijat' sa ne- 
mohúcne na kolenách, ale im bez váhania podala pomocnú ruku!“ (Habaj 1986, 285). Autor s neskrývaným entuziazmom opisuje obnovenie Lipovej Osady, okolia, okresu, kraja - teda Žitného ostrova. Vyslovuje tichý pocit vd'aky za nové rozostavané ulice a symbolické svetlá. Nové dni tak vítalo „slnko, ktoré sa vo vode odrážalo, s približujúcim sa večerom postupne prechádzalo do sýtejších červených odtieňov, dodávalo okolitej krajine nezvyčajný, ale mierumilovný ráz..." (Habaj 1986, 266). Z rozmočenej zeme vyhúkli milióny výhonkov rozmanitých rastliniek, tráv a byliniek. Svedčilo to o neprestajnom kolobehu racionálneho l'udského bytia. Mimoriadna štátna podpora viedla $\mathrm{k}$ tomu, aby l'udia chceli a mohli so stúpajúcim optimizmom stavat' nielen nové (tentoraz už murované) domy, ale aj nádeje. Premena človeka tak išla ruka v ruke s obnovou Lipovej Osady, chudobní sa stali bohatšími... a tak je to správne. Pohl'ad do budúcnosti je však, azda pochopitel'ne, opät' kontaminovaný pohl'adom do minulosti. Záverečná cesta na cintorín je symbolom pominutel'nosti, akéhosi uvol'nenia priestoru pôvodných usadlikov novým pokoleniam. Starí kolonisti si, prirodzene, uvedomujú premenlivost' sveta, sú však zmierení a majú pokoj v duši, ved': „všetko, čo tu vykonalo pokolenie zakladatel'ov osady, jeho generácia, je iba jeden z množstva tenučkých pramienkov, ktorými po stáročia prúdila na Dolniaky čerstvá, zdravá krv z hornatejších krajov, tá krv, čo sa tu potom riedila, rozpúštala, strácala v mori inej krvi, len nepatrná čiastka rieky, čo od vekov steká zo severu na juh, mihne sa časom, zablikoce pri púti dejinami svetielkom svojho rodokmeňa, vzápätí však zhasne, zhltne ju tma, a hoci aj vieš, tušiš, že je stále kdesi tu, že tu musí niekde byt', predsa tu už nie je, lebo svetielko nebliká, nemáš sa o čo opriet' v tom tvojom tušení [...] Či sa má teraz, odchádzajúc, odchádzajúc odtial'to i odvšade, naozaj zmierit’ s touto strašnou myšlienkou?" (Habaj 1986, 299-300).

\section{Literatúra}

Bagin, Albín (1981): Albín Bagin číta Ivana Habaja. Romboid, roč. 16, č. 2, s. 41-44.

Bartko, Michal (1986): Človek v dejinách: zavŕšila sa dolniacka trilógia Ivana Habaja. Práca, roč. 41 , č. 300 , s. 6 .

Borčin, Emil (1987): S hodnotami nemožno hazardovat: Cena A. Zápotockého prozaikovi Ivanovi Habajovi. Práca, roč. 42, č. 52, s. 4.

Brušák, Karel (1988): Zobrazenie skutočnosti v Habajových Kolonistoch. Romboid, roč. 23, č. 7, s. 58-65.

Bugárová, Mária (1985): Od poviedok k románovej trilógii. Rozhlas, roč. 47, č. 36, s. 3.

Bžoch, Jozef (1987): Kolonisti Ivana Habaja. L'ud, roč. 40, č. 25, s. 4.

Čúzy, Ladislav (1986): Syntéza a hl'adanie novej témy. Slovenské pohlady, roč. 102, č. 2 , s. $110-121$.

Diskusia o Habajových Kolonistoch (1981a): Slovenské pohlady, roč. 97, č. 4, s. 159. (autor neuvedený)

Ďalšia románová epopeja (1981b): Slovensko, roč. 5, č. 1, s. 6. (autor neuvedený)

Fazekašová, Magdaléna (1983): Jazykové vyjadrenie času ako kompozičného činitel'a v románe I. Habaja Kolonisti. Slovenská reč, roč. 48, č. 3, s. 147-152. 
Gallo, Igor (1994): Kolonisti v premenách času: hovorime so spisovatel'om Ivanom Habajom. Literárny týždenník, roč. 7, č. 36, s. 1 a 11.

Gombala, Eduard (1980): Slovenský juh v próze. Pravda, roč. 61, č. 14, s. 5.

Habaj, Ivan (1980a): Kolonisti I. Bratislava: Slovenský spisovatel'.

Habaj, Ivan (1981a): Kolonisti II. Bratislava: Slovenský spisovatel'.

Habaj, Ivan (1986): Kolonisti III. Bratislava: Slovenský spisovatel'.

https://chamo.kis3g.sk/lib/item?id=chamo:85867 \&theme=systemHabaj, Ivan (1982): Navyše. Romboid, roč. 17, č. 8, s. 25.

Habaj, Ivan (1980b): Pohl'ad z dielne. Nové slovo mladých, roč. 3, č. 12, s. 1.

Habaj, Ivan (1981b): Řekli o sobě. Nové knihy, roč. 20, č. 15, s. 6.

Hajdani, Gejza (1986): Prestiž spisovatel'a klesá. Večerník, roč. 31, č. 229, s. 6-7.

Halvoník, Alexander (1981): Vstup do rozsiahlejšieho cyklu: zamýšl'ame sa nad románom Ivana Habaja Kolonisti I. Práca, roč. 36, č. 54, s. 6.

Chmel, Rudolf (1981): Habajova románová premiéra. Slovenské pohlady, roč. 97, č. 4, s. 109-112.

Chmel, Rudolf (1983): Ivan Habaj - Kolonisti II. Slovenské pohlady, roč. 99, č. 6, s. 132-135.

(jf, 1981): Kniha a tvorca - Ivan Habaj. Ĺud, roč. 34, č. 52, s. 5.

(1983) JUDr. Ivan Habaj. Čitatel', roč. 32, č. 4, s. 4. (autor neuvedený)

Kamenistý, Ján (1981): Próza na juhu: hovoríme s prozaikom Ivanom Habajom. Smena na nedel'u, roč. 16 , č. 46 , s. 6.

Kapsová, Eva (1988): Poetika Habajovej cesty k súčasnosti. Romboid, roč. 23, č. 8, s. 109-113.

Kochol, Viktor (1982): Epopeja slovenského juhu. Slovenské pohl'ady, roč. 98, č. 5, s. 107-114.

Kochol, Viktor (1981): Triumf románu. Slovenské pohl'ady, roč. 97, č. 6, s. 79-87.

Machala, Lubomir (1989): K poetike prozaického diela Ivana Habaja. Romboid, roč. 24, č. 1, s. 50-55.

Mikolaj, Dušan (1983): Pribehy o l'ud'och zo Žitného ostrova. Slovensko, roč. 7, č. 5, s. 8-9.

Noge, Július (1987): Na tažkej trati bez rekordu. Romboid, roč. 22, č. 6, s. 76-78.

Observátor IV. (1981): Ivan Habaj - Kolonisti I. Romboid, roč. 16, č. 8, s. 94-95. (autor: Valér Mikula)

Obuch, Oto (1986): Ĺudské osudy v diele I. Habaja. Sloboda, roč. 41, č. 28 , s. 4.

Petrik, Vladimír (1982a): Človek ešte žije. Nové slovo, roč. 24, č. 39 (Nedel'a - priloha Nového slova, č. 17, s. 7.)

Petrik, Vladimír (1982b): Kolonisti sa vracajú. Nové slovo, roč. 24, č. 23 (Priloha Nového slova, č. 5, s. 6-7.)

Petrík, Vladimír (1981): Román slovenského juhu: k prvému dielu Kolonistov Ivana Habaja. Nové slovo, roč. 23, č. 24, s. 16.

(pš, 1987): Dokončená trilógia. Nové knihy, roč. 26, č. 4, s. 1. (autor: Pavol Števček)

(pš, 1982): Kolonisti pokračujú. Nové knihy. roč. 21, č. 8, s. 6. (autor: Pavol Števček) 
Pynsent, Robert Burton (1989): Národnosti južného Slovenska v Habajových a Ballekových dielach. Romboid, roč. 24, č. 6, s. 77-81.

Svetoň, Ĺuboš (1992a): Rovina je pre mňa chrámom: rozhovor Slovenskej nedele so spisovatel'om Ivanom Habajom. Slovenská nedel'a - magazínová príloha Slovenského denníka, roč. 2 , č. 18 , s. 3.

Svetoň, Ĺuboš (1992b): Stratená varta: Ivan Habaj, spisovatel' a právnik. Národná osveta, roč. 2, č. 4, s. 2-3.

Šabík, Vincent (1986): Kolonisti III - pririečny svet Ivana Habaja. Nové slovo, roč. 28, č. 42, s. 5.

Truhlár̆, Břetislav (1981): Habajov prvý diel Kolonistov. Pravda, roč. 62, č. 202, s. 5.

Truhlár̆, Břetislav (1982a): Kritici diskutujú o Habajových Kolonistoch. Romboid, roč. 17, č. 8, s. $19-25$.

Truhlár̆, Břetislav (1982b): Odkrývanie d'alších osudov: nad druhým dielom Habajových KoIonistov. Pravda, roč. 63, č. 98, s. 5.

Truhlár̆, Břetislav (1987): Zavŕšenie trilógie Ivana Habaja Kolonisti. Pravda, roč. 68, č. 94 , s. 5.

Truhlár̆, Břetislav (1985): Životné osudy. Romboid, roč. 20, č. 1, s. 88.

https://chamo.kis3g.sk/lib/item?id=chamo:152433\&theme=systemVel'ký, Jozef (1984): Pisané životnou pravdou. Pravda, roč. 65, č. 209, s. 5.

-w- (1981): Kolonisti. Život, roč. 31, č. 4, s. 59.
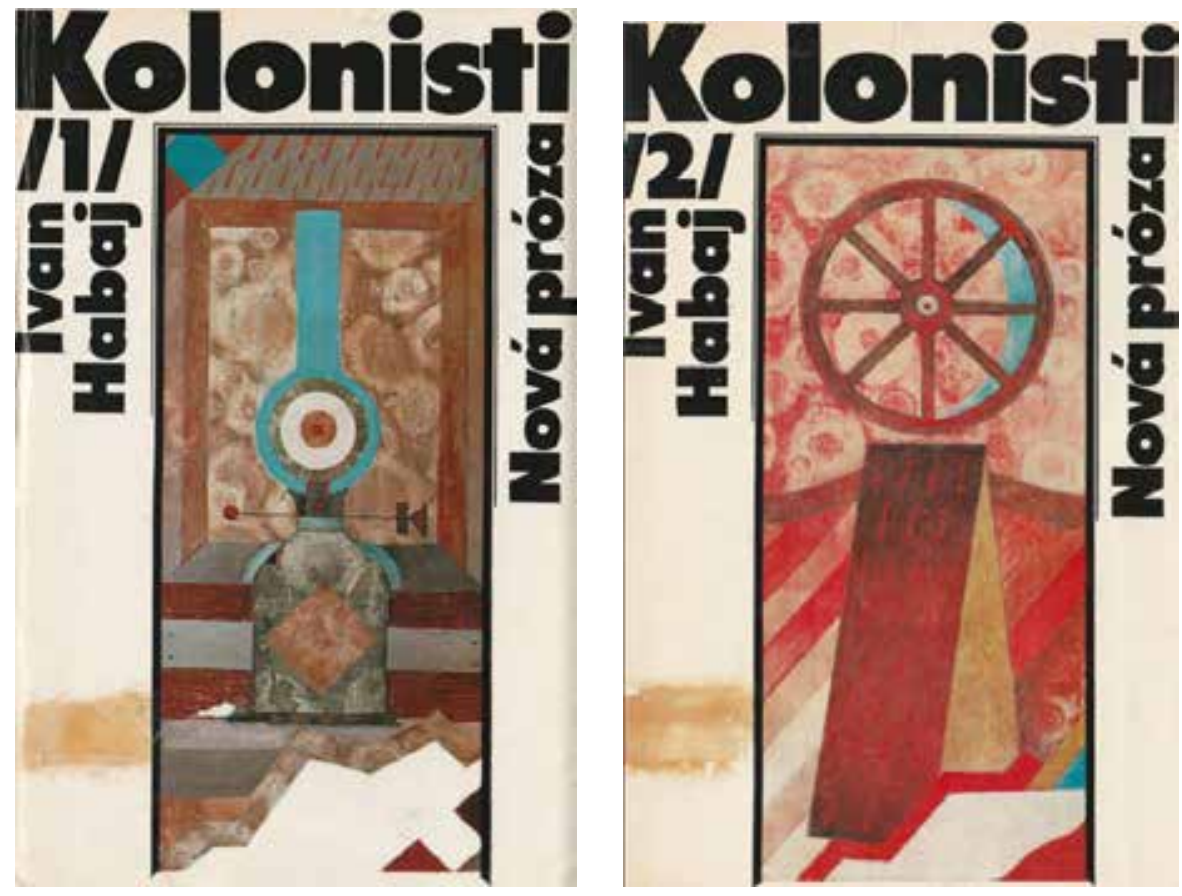

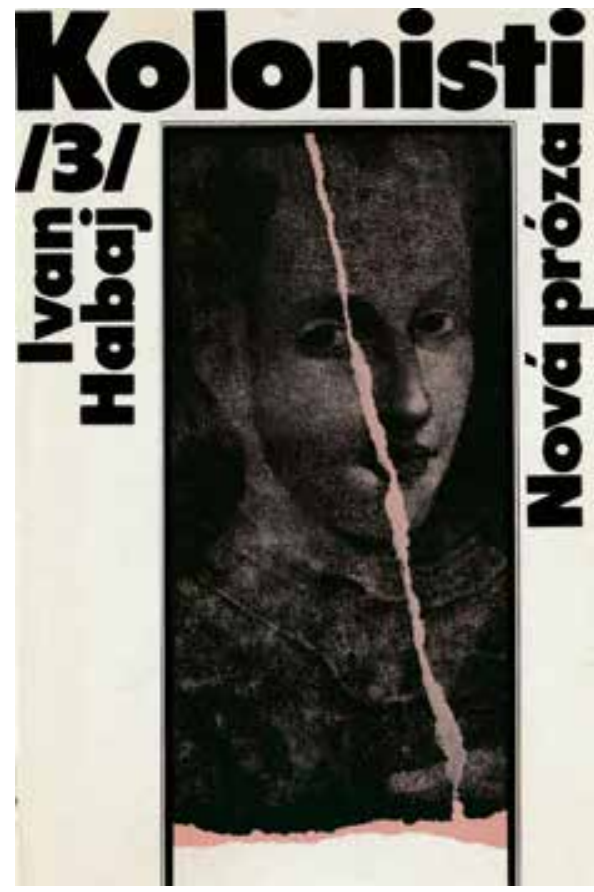

Bdecine venof

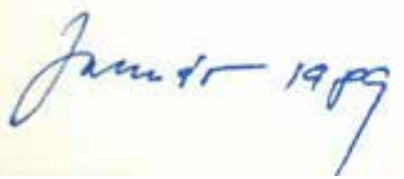

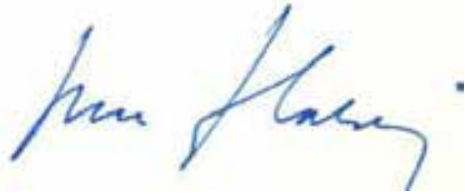

